\title{
Macrooxazoles A-D, New 2,5-Disubstituted Oxazole-4-Carboxylic Acid Derivatives from the Plant Pathogenic Fungus Phoma macrostoma
}

\author{
Blondelle Matio Kemkuignou ${ }^{1,2,+}$, Laura Treiber ${ }^{3,+}$, Haoxuan Zeng ${ }^{1,2}$, Hedda Schrey ${ }^{1,2}$, \\ Rainer Schobert ${ }^{3}$ (D) and Marc Stadler $1,2, *$ (D) \\ 1 Department of Microbial Drugs, Helmholtz Centre for Infection Research GmbH, Inhoffenstrasse \\ 7, 38124 Braunschweig, Germany; blondelle.matiokemkuignou@helmholtz-hzi.de (B.M.K.); \\ haoxuan.zeng@helmholtz-hzi.de (H.Z.); hedda.schrey@helmholtz-hzi.de (H.S.) \\ 2 German Centre for Infection Research (DZIF), partner site Hannover-Braunschweig, Inhoffenstrasse 7, \\ 38124 Braunschweig, Germany \\ 3 Organic chemistry laboratory, University of Bayreuth, Universitaetsstrasse 30, 95447 Bayreuth, Germany; \\ Laura1.Treiber@uni-bayreuth.de (L.T.); Rainer.Schobert@uni-bayreuth.de (R.S.) \\ * Correspondence: marc.stadler@helmholtz-hzi.de; Tel.: +49-531-6181-4240; Fax: +49-531-6181-9499 \\ + These authors contributed equally to this work.
}

Academic Editors: Daniel Krug and Lena Keller

Received: 7 November 2020; Accepted: 23 November 2020; Published: 24 November 2020

\begin{abstract}
In our ongoing search for new bioactive fungal metabolites, four previously undescribed oxazole carboxylic acid derivatives (1-4) for which we proposed the trivial names macrooxazoles A-D together with two known tetramic acids (5-6) were isolated from the plant pathogenic fungus Phoma macrostoma. Their structures were elucidated based on high-resolution mass spectrometry (HR-MS) and nuclear magnetic resonance (NMR) spectroscopy. The hitherto unclear structure of macrocidin Z (6) was also confirmed by its first total synthesis. The isolated compounds were evaluated for their antimicrobial activities against a panel of bacteria and fungi. Cytotoxic and anti-biofilm activities of the isolates are also reported herein. The new compound 3 exhibited weak-to-moderate antimicrobial activity as well as the known macrocidins $\mathbf{5}$ and $\mathbf{6}$. Only the mixture of compounds $\mathbf{2}$ and $\mathbf{4}$ (ratio 1:2) showed weak cytotoxic activity against the tested cancer cell lines with an $\mathrm{IC}_{50}$ of $23 \mu \mathrm{g} / \mathrm{mL}$. Moreover, the new compounds 2 and 3, as well as the known compounds 5 and 6, interfered with the biofilm formation of Staphylococcus aureus, inhibiting 65\%, 75\%, 79\%, and $76 \%$ of biofilm at $250 \mu \mathrm{g} / \mathrm{mL}$, respectively. Compounds 5 and $\mathbf{6}$ also exhibited moderate activity against $S$. aureus preformed biofilm with the highest inhibition percentage of $75 \%$ and $73 \%$ at $250 \mu \mathrm{g} / \mathrm{mL}$, respectively.
\end{abstract}

Keywords: Phoma macrostoma; oxazole derivatives; anti-biofilm; isolation; structure elucidation; macrocidin $Z$ synthesis

\section{Introduction}

Oxazole and its derivatives are heterocyclic systems which have gained strong interest in recent times due to their increasing importance in the field of medicinal chemistry [1]. They feature a well-known important doubly unsaturated 5-membered ring heterocyclic motif having one oxygen atom at position 1 and a nitrogen at position 3 separated by a carbon in between [2]. Their widespread useful biological activities including antimicrobial [3], anticancer [4], antitubercular [5], anti-inflammatory [6], antidiabetic [7], antiobesity [8] and anthelminthic [9] effects have attracted increasing attention of chemical and pharmacological communities in their search for new lead compounds [1]. Some of 
them have shown promising therapeutic potential and have qualified for both preclinical and clinical evaluations [2]. Previous studies reported the isolation of several biologically active substituted oxazole-containing natural products mostly from marine invertebrates and microorganisms $[2,10,11]$. For instance, hennoxazole A, isolated from a marine sponge Polyfibrospongia sp., was reported to possess antiviral activity $[12,13]$ while the phthoxazolins isolated from Streptomyces sp. showed selective activity against the oomycete Phytophthora parasitica in vitro [14]. As part of our ongoing search of exploring fungi for new biologically active metabolites, we investigated the chemical components of the fermentation extract of the plant pathogenic fungus Phoma macrostoma originally isolated from its host, the noxious weed, Cirsium arvense. Previous investigations indicated that the liquid culture of the fungus could produce phytotoxic metabolites named macrocidins, which also caused bleaching when applied foliarly to several dicotyledonous species $[15,16]$. In the present work, four previously undescribed oxazole-4-carboxylic acid derivatives (1-4) together with two known macrocidins (5-6) were isolated from the liquid culture of Phoma macrostoma. The structures of the isolates were elucidated by means of high resolution electro spray ionization mass spectrometry (HR-ESIMS) data and 1D and 2D nuclear magnetic resonance (NMR) spectroscopic data. The so far contentious structure of macrocidin $\mathrm{Z}$ (6) was also confirmed by comparison of the isolate with the product of its first total synthesis. All compounds were investigated for antimicrobial and cytotoxic effects. The current paper reports details of their isolation, structural elucidation and biological activities.

\section{Results and Discussion}

\subsection{Structure Elucidation of Compounds 1-6}

Liquid fermentation in Q6 $\frac{1}{2}$ medium of Phoma macrostoma was carried out as described in the Materials and Methods section. The major metabolites were detected by analytical high performance liquid chromatography (HPLC) as shown in Figure 1 and the preparative HPLC separation to obtain the pure metabolites was guided accordingly. Fractionation of the crude extract using reverse-phase HPLC led to the isolation of four previously undescribed metabolites (1-4), together with two known compounds, the macrocidins A (5) and Z (6) (Figure 2). Macrocidin A (5) was identified by comparing its NMR and HR-ESIMS data with those reported in the literature [15]. Its absolute configuration was confirmed to be identical to that of the synthetic macrocidin A [17] by comparison of their respective Electronic Circular Dichroism (ECD) spectra (Figure 3). As the structure of macrocidin Z (6) was unclear so far [16], we synthesized it for the first time (Scheme 1) and found a perfect match of the ${ }^{1} \mathrm{H}$ and ${ }^{13} \mathrm{C}$-NMR data, as well as of the ECD spectra of the synthetic and the isolated macrocidin $\mathrm{Z}$ samples (see Table 1 and Figure 3). The E-geometry of the $\Delta^{16-17}$ double bond in macrocidin $Z$ was determined based on the existence of a coupling constant $J=15.5 \mathrm{~Hz}$ between $\mathrm{H}-16$ and H-17. 


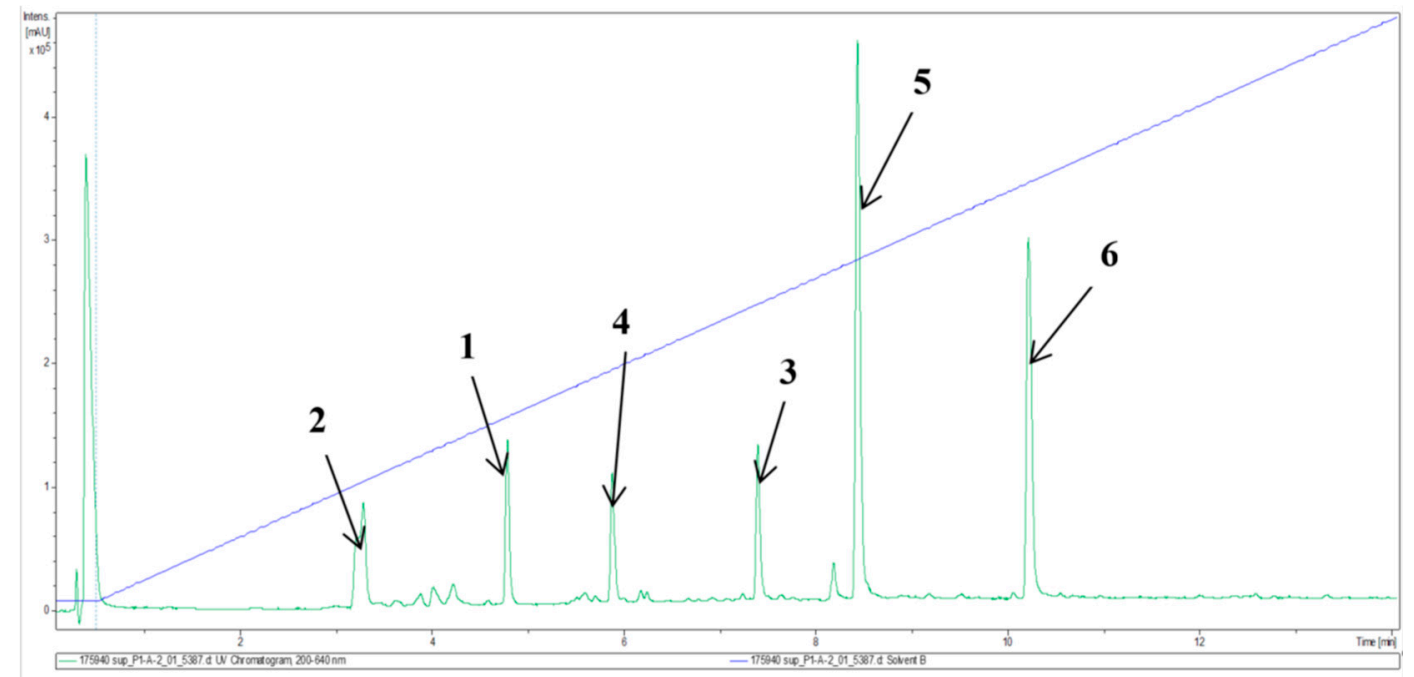

Figure 1. Analytical HPLC-UV/Vis chromatogram of the crude extract from the supernatant of Phoma macrostoma (diode array detection at 200-640 nm). Stationary phase: C18 Acquity UPLC BEH column; for gradient and other details on the experimental setup, see the Experimental section; 1-6: Major metabolites detected (chemical structures see Figure 2). \% solvent B (acetonitrile (ACN) $+0.1 \%$ formic acid $5-100 \%$ ). Gradient is indicated by the blue line.<smiles>COC(=O)c1nc(Cc2ccc(O)cc2)oc1CCO</smiles><smiles>COC(=O)c1nc(Cc2ccc(O)cc2)oc1C(O)CO</smiles><smiles>C=Cc1oc(Cc2ccc(O)cc2)nc1C(=O)OC</smiles><smiles>COC(=O)c1nc(Cc2ccc(O)cc2)oc1C1CO1</smiles><smiles></smiles>

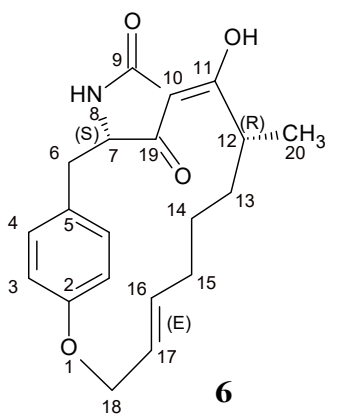<smiles>CC(C)=CCC/C(C)=C/CC/C(C)=C/CC/C(C)=C/CO[C@H](C(=O)O)[C@@H](CC(=O)O)C(=O)O</smiles>

Figure 2. Chemical structures of secondary metabolites isolated from Phoma macrostoma (1-6) and the known biofilm inhibitor microporenic acid A (7). 


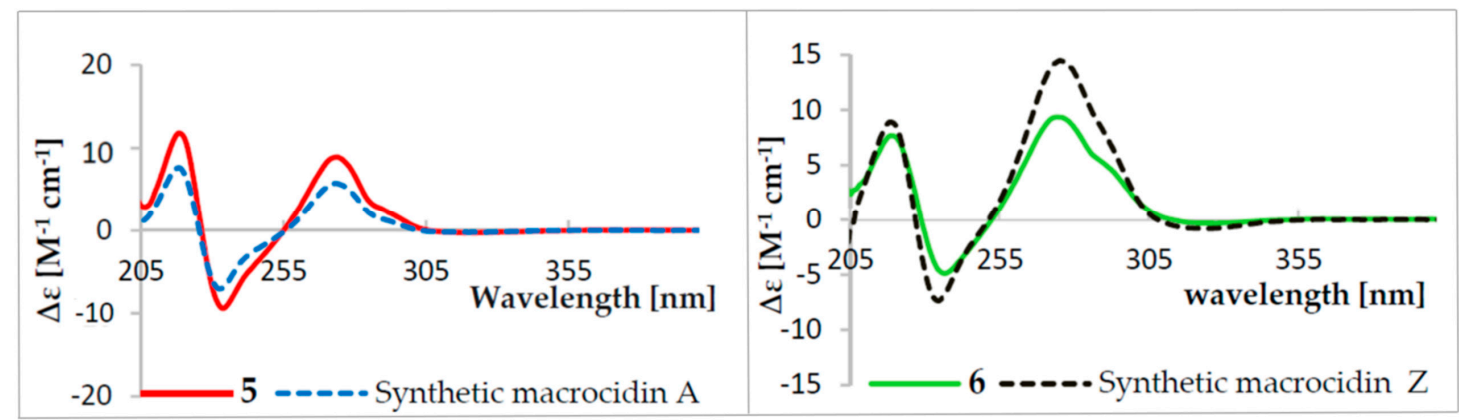

Figure 3. ECD spectra of isolated and synthetic macrocidins A (5) and Z (6) in $\mathrm{MeOH}$.

Compound 1 was isolated as a yellow oil from both the supernatant and the mycelia. Its molecular formula was established as $\mathrm{C}_{14} \mathrm{H}_{15} \mathrm{NO}_{5}$ (8 degrees of unsaturation) based on its $[\mathrm{M}+\mathrm{H}]^{+}$ion at $\mathrm{m} / \mathrm{z}$ 278.1026 and $[\mathrm{M}+\mathrm{Na}]^{+}$ion at $m / z 300.0837$ in the HR-ESIMS.

The ${ }^{1} \mathrm{H}-\mathrm{NMR}$ spectroscopic data coupled to the ${ }^{1} \mathrm{H}-{ }^{1} \mathrm{H}$ correlation spectroscopy $\left({ }^{1} \mathrm{H}-{ }^{1} \mathrm{H}\right.$ COSY $)$ spectrum revealed two doublets resonating at $\delta 7.10(\mathrm{H}-8 / \mathrm{H}-12, \mathrm{~d}, 9.0)$ and $\delta 6.73(\mathrm{H}-9 / \mathrm{H}-11, \mathrm{~d}, 9.0)$ integrating for two aromatic protons each, suggesting a 1,4-disubstituted aromatic ring. One methoxy group singlet resonating at $\delta 3.87(\mathrm{H}-14, \mathrm{~s})$, a singlet methylene resonating at $\delta 4.00(\mathrm{H}-6, \mathrm{~s})$, a triplet for methylene protons resonating at $\delta 3.19(\mathrm{H}-15, \mathrm{t}, 6.5)$, and linked to an oxygenated methylene at $\delta 3.80$ $(\mathrm{H}-16, \mathrm{t}, 6.5)$ were also recorded.

The ${ }^{13} \mathrm{C}$-NMR spectrum showed 12 carbon signals instead of 14 as indicated by the molecular formula suggesting the presence of symmetrical carbons and thus confirming the existence of a 1,4-disubstituted aromatic ring. The 12 carbons were further identified as one methoxy, two methylene, one oxymethylene, two aromatic methine carbons and six non-protonated $\mathrm{sp}^{2}$ carbons from detailed analysis of its ${ }^{1} \mathrm{H}_{-}{ }^{13} \mathrm{C}$ heteronuclear single quantum coherence $\left({ }^{1} \mathrm{H}_{-13}{ }^{13} \mathrm{C} \mathrm{HSQC}\right)$ spectrum (Table 2). The gross structure of $\mathbf{1}$ was determined by comprehensive analysis of its 2D NMR including the COSY, HMBC (heteronuclear multiple bond correlation) and NOESY (nuclear overhauser effect spectroscopy) spectra. The chemical shifts of the aromatic carbons as well as the HMBC correlations of H-8/H-12 to C-10 ( $\delta$ 157.9)/C-6 ( $\delta 34.3), \mathrm{H}-9 / \mathrm{H}-11$ to C-10 $(\delta 157.9) / \mathrm{C}-7$ ( $\delta 127.0)$ and H-6 to C-7 $(\delta 127.0) / C-8(\delta 131.0)$ indicated a benzyl group with an oxygen substitution para to the methylene leading to a para-hydroxybenzyl moiety. 
Table 1. ${ }^{13} \mathrm{C}$ and ${ }^{1} \mathrm{H}-\mathrm{NMR}$ spectroscopic data $\left({ }^{1} \mathrm{H} 500 \mathrm{MH}_{\mathrm{Z}},{ }^{13} \mathrm{C} 125 \mathrm{MH}_{\mathrm{Z}}\right.$ in Methanol- $d_{4}, \delta$ in ppm) for isolated and synthetic compound $\mathbf{6}$.

\begin{tabular}{|c|c|c|c|c|}
\hline \multirow{2}{*}{ Position } & \multicolumn{2}{|r|}{6} & \multicolumn{2}{|c|}{ Synthetic 6} \\
\hline & $\delta_{\mathrm{C}}$, Type & $\delta_{\mathrm{H}}(J$ in $\mathrm{Hz})$ & $\delta_{\mathrm{C}}$, Type & $\delta_{\mathrm{H}}(J$ in $\mathrm{Hz})$ \\
\hline 2 & $157.4, \mathrm{C}$ & & 157.3, C & \\
\hline $3 / 21$ & $115.9, \mathrm{CH}$ & $6.69, \mathrm{~m}$ & 115.7, CH & $6.71, \mathrm{~m}$ \\
\hline $4 / 22$ & $132.6, \mathrm{CH}$ & $6.98, \mathrm{~m}$ & $132.5, \mathrm{CH}$ & 6.97, m \\
\hline 5 & $127.6, \mathrm{C}$ & & 127.3, C & \\
\hline 6 & $36.6, \mathrm{CH}_{2}$ & 3.07, dd $(14.1,3.9)$ & $36.5, \mathrm{CH}_{2}$ & 3.07, dd $(14.1,3.9)$ \\
\hline & & $2.90, \mathrm{dd}(14.1,3.3)$ & & 2.89, dd $(14.1,3.1)$ \\
\hline 7 & $63.8, \mathrm{CH}$ & $4.10, \mathrm{t}(3.6)$ & $63.8, \mathrm{CH}$ & $4.10, \mathrm{~m}$ \\
\hline 9 & $177.3, \mathrm{C}$ & & $175.5, \mathrm{C}$ & \\
\hline 10 & 102.3, C & & 102.1, C & \\
\hline 11 & 194.0, C & & 191.8, C & \\
\hline 12 & $37.2, \mathrm{CH}$ & 3.40, sxt (6.8) & $36.8, \mathrm{C}$ & 3.39, sxt (6.8) \\
\hline 13 & $35.3, \mathrm{CH}_{2}$ & $\begin{array}{c}1.16, \operatorname{tdd}(12.9,6.4,4.3) \\
1.09, \mathrm{~m}\end{array}$ & $35.1, \mathrm{CH}_{2}$ & $1.13, \mathrm{~m}$ \\
\hline 14 & 28.3, $\mathrm{CH}_{2}$ & $\begin{array}{c}0.83, \text { tddd }(12.9,8.5,6.5,4.4) \\
1.32, \mathrm{~m}\end{array}$ & 28.1, $\mathrm{CH}_{2}$ & $\begin{array}{l}0.83, \mathrm{~m} \\
1.32, \mathrm{~m}\end{array}$ \\
\hline 15 & $33.6, \mathrm{CH}_{2}$ & $\begin{array}{c}2.06, \mathrm{dq}(12.8,6.2) \\
1.79, \mathrm{~m}\end{array}$ & $33.4, \mathrm{CH}_{2}$ & $\begin{array}{l}2.06, \mathrm{~m} \\
1.79, \mathrm{~m}\end{array}$ \\
\hline 16 & $139.1, \mathrm{CH}$ & 5.67, ddd $(15.5,8.8,5.9)$ & 139.0, $\mathrm{CH}$ & $5.68, \mathrm{~m}$ \\
\hline 17 & $126.6, \mathrm{CH}$ & 5.26, ddd $(15.5,8.9,3.8)$ & 126.7, CH & $5.26, \mathrm{~m}$ \\
\hline 18 & $68.1, \mathrm{CH}_{2}$ & $\begin{array}{l}4.64, \text { dd }(13.4,8.9) \\
4.53, \text { dd }(13.4,3.8)\end{array}$ & $67.9, \mathrm{CH}_{2}$ & $\begin{array}{c}4.64, \mathrm{dd}(13.4,9.5) \\
4.53, \mathrm{~m}\end{array}$ \\
\hline 19 & 197.3, C & & 197.1, C & \\
\hline 20 & $15.4, \mathrm{CH}_{3}$ & $1.05, \mathrm{~d}(6.8)$ & $15.2, \mathrm{CH}_{3}$ & \\
\hline
\end{tabular}

Table 2. ${ }^{13} \mathrm{C}$ and ${ }^{1} \mathrm{H}-\mathrm{NMR}$ spectroscopic data $\left({ }^{1} \mathrm{H} 500 \mathrm{MH}_{\mathrm{Z}},{ }^{13} \mathrm{C} 125 \mathrm{MH}_{\mathrm{Z}}\right.$ in Methanol- $d_{4}, \delta$ in ppm) for compounds 1 and 2.

\begin{tabular}{|c|c|c|c|c|}
\hline \multirow{2}{*}{ Position } & \multicolumn{2}{|c|}{1} & \multicolumn{2}{|c|}{2} \\
\hline & $\delta_{\mathrm{C}}$, Type & $\delta_{\mathrm{H}}(J$ in $\mathrm{Hz})$ & $\delta_{\mathrm{C}}$, Type & $\delta_{\mathrm{H}}(J$ in $\mathrm{Hz})$ \\
\hline 2 & $164.4, \mathrm{C}$ & - & $165.1, \mathrm{C}$ & - \\
\hline 4 & $129.0, \mathrm{C}$ & - & $129.6, \mathrm{C}$ & - \\
\hline 5 & 159.1, C & - & $159.3, \mathrm{C}$ & - \\
\hline 6 & $34.3, \mathrm{CH}_{2}$ & $4.00, \mathrm{~s}$ & $34.3, \mathrm{CH}_{2}$ & $4.04, \mathrm{~s}$ \\
\hline 7 & 127.0, C & - & $126.9, \mathrm{C}$ & - \\
\hline 8 & 131.0, $\mathrm{CH}$ & $7.10, \mathrm{~d}(9.0)$ & 131.0, $\mathrm{CH}$ & $7.12, \mathrm{~d}(9.0)$ \\
\hline 9 & $116.7, \mathrm{CH}$ & $6.73, \mathrm{~d}(9.0)$ & $116.7, \mathrm{CH}$ & $6.73, \mathrm{~d}(9.0)$ \\
\hline 10 & $157.9, \mathrm{C}$ & - & $158.0, \mathrm{C}$ & - \\
\hline 11 & $116.7, \mathrm{CH}$ & $6.73, \mathrm{~d}(9.0)$ & $116.7, \mathrm{CH}$ & $6.73, \mathrm{~d}(9.0)$ \\
\hline 12 & 131.0, $\mathrm{CH}$ & $7.10, \mathrm{~d}(9.0)$ & 131.0, $\mathrm{CH}$ & $7.12, \mathrm{~d}(9.0)$ \\
\hline 13 & $163.9, \mathrm{C}$ & - & 163.6, C & - \\
\hline 14 & $52.4, \mathrm{CH}_{3}$ & $3.87, \mathrm{~s}$ & 52.6, $\mathrm{CH}_{3}$ & $3.88, \mathrm{~s}$ \\
\hline 15 & $30.8, \mathrm{CH}_{2}$ & $3.19, \mathrm{t}(6.5)$ & $67.3, \mathrm{CH}$ & $5.33, \mathrm{t}(6.5)$ \\
\hline 16 & $60.6, \mathrm{CH}_{2}$ & $3.80, \mathrm{t}(6.5)$ & $65.1, \mathrm{CH}_{2}$ & $\begin{array}{l}3.73 \text {, dd }(11,6.5) \\
3.78, \text { dd }(11,6.5)\end{array}$ \\
\hline
\end{tabular}

The presence of a methyl-2,5-disubstituted oxazole-4-carboxylate moiety was evidenced by resonance of $\mathrm{sp}^{2}$ carbon signals at $\delta 164.4(\mathrm{C}-2), \delta 159.1$ (C-5), $\delta 129.0(\mathrm{C}-4), \delta 163.9(\mathrm{C}-13)$, and a methoxy carbon at $\delta 52.4(\mathrm{C}-14)$. This was further confirmed by HMBC correlations between H-15 $(\delta 3.19)$ and

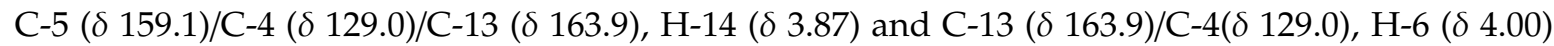
and C-2 $(\delta 164.4)$ as well as the ${ }^{15} \mathrm{~N}-{ }^{1} \mathrm{H}$ HMBC correlation of H-6 $(\delta 4.00)$ to N-3 $(\delta 244.1)$ (Figure 4$)$. The HMBC correlations of H-6 $(\delta 4.00)$ to C-2 $(\delta 164.4)$ and N-3 $(\delta 244.1)$ revealed the connectivity of the para-hydroxybenzyl moiety to the C-2 carbon of the oxazole moiety confirming unambiguously 
the structure of compound $\mathbf{1}$ as methyl 5-(2-hydroxyethyl)-2-(4-hydroxybenzyl)-oxazole-4-carboxylate, named macrooxazole A.
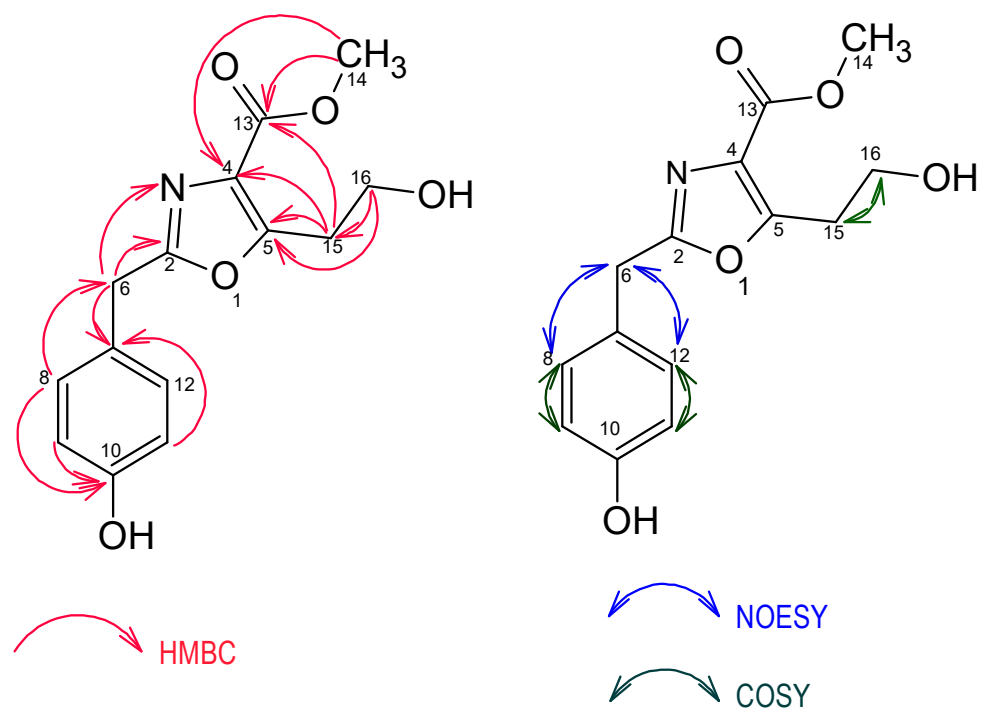

Figure 4. Key HMBC, COSY and NOESY correlations of compound 1.

Compound 2 was obtained as a yellow oil from both supernatant and mycelia. Its molecular formula $\mathrm{C}_{14} \mathrm{H}_{15} \mathrm{NO}_{6}$ (8 degrees of unsaturation) was determined by the $[\mathrm{M}+\mathrm{H}]^{+}$ion at $\mathrm{m} / z 294.0974$, $[\mathrm{M}+\mathrm{Na}]^{+}$ion at $m / z 316.0788$ and $\left[\mathrm{M}+\mathrm{H}-\mathrm{H}_{2} \mathrm{O}\right]^{+}$ion at $m / z 276.0865$ from the HR-ESIMS data (positive mode). Its NMR spectroscopic data displayed high similarities to those of compound 1, suggesting that they are close analogues. The only structural difference was the presence of the hydroxyl group at $\mathrm{C}-15$ of compound $\mathbf{2}$ which was absent in compound $\mathbf{1}$. This was confirmed not only by the ${ }^{1} \mathrm{H}-{ }^{1} \mathrm{H}$ COSY coupling of $\mathrm{H}-15(\delta 5.33)$ to $\mathrm{H}-16 \mathrm{a}(\delta 3.73) / \mathrm{H}-16 \mathrm{~b}(\delta 3.78)$ but also by the HMBC correlation between $\mathrm{H}-15(\delta 5.33)$ and $\mathrm{C}-16(\delta 65.1)$. Interestingly, obtaining an optical rotation value approaching zero identified compound 2 to be a racemic mixture. Consequently, compound 2 was determined as a racemic mixture of methyl 5-(1,2-dihydroxyethyl)-2-(4-hydroxybenzyl)-oxazole-4-carboxylate, named macrooxazole B.

The molecular formula of compound 3 isolated from both supernatant and mycelia as a brown oil was established as $\mathrm{C}_{14} \mathrm{H}_{13} \mathrm{NO}_{4}$ (9 degrees of unsaturation) from the HR-ESIMS which showed an $[\mathrm{M}+\mathrm{H}]^{+}$ion at $m / z 260.0917$ and an $[\mathrm{M}+\mathrm{Na}]^{+}$ion at $m / z$ 282.0737. Analysis of $1 \mathrm{D}$ and 2D NMR revealed a similar structure to 1 with the $\mathrm{C}-16$ hydroxyl group missing in compound 3 , but a double bond $\Delta^{15-16}$ at $\delta 123.2$ (C-15) and $\delta 121.0$ (C-16) were recorded instead (Table 3). The H-15 $(\delta 7.14)$ showed COSY correlations to H-16a $(\delta 5.58) / \mathrm{H}-16 \mathrm{~b}(\delta 5.96)$ and HMBC correlations to C-5 ( $\delta$ $155.6) / C-16(\delta 121.0)$ confirming the structure of the previously unreported metabolite 3 as methyl 2-(4-hydroxybenzyl)-vinyloxazole-4-carboxylate, named macrooxazole C. 
Table 3. ${ }^{13} \mathrm{C}$ and ${ }^{1} \mathrm{H}-\mathrm{NMR}$ spectroscopic data $\left({ }^{1} \mathrm{H} 500 \mathrm{MH}_{\mathrm{Z}},{ }^{13} \mathrm{C} 125 \mathrm{MH}_{\mathrm{Z}}\right.$ in Methanol- $d_{4}, \delta$ in ppm) for compounds 3 and 4 .

\begin{tabular}{|c|c|c|c|c|}
\hline \multirow{2}{*}{ Position } & \multicolumn{2}{|c|}{3} & \multicolumn{2}{|c|}{4} \\
\hline & $\delta_{\mathrm{C}}$, Type & $\delta_{\mathrm{H}}(J$ in $\mathrm{Hz})$ & $\delta_{\mathrm{C}}$, Type & $\delta_{\mathrm{H}}(J$ in $\mathrm{Hz})$ \\
\hline 2 & $164.8, \mathrm{C}$ & - & $165.3, \mathrm{C}$ & - \\
\hline 4 & 128.1, C & - & $133.0, \mathrm{C}$ & - \\
\hline 5 & 155.6, C & - & 155.1, C & - \\
\hline 6 & $34.3, \mathrm{CH}_{2}$ & $4.04, \mathrm{~s}$ & $34.2, \mathrm{CH}_{2}$ & $4.00, \mathrm{~s}$ \\
\hline 7 & $126.8, \mathrm{C}$ & - & $126.6, \mathrm{C}$ & \\
\hline 8 & 131.0, $\mathrm{CH}$ & $7.12, \mathrm{~d}(9.0)$ & 131.0, CH & $7.08, \mathrm{~d}(9.0)$ \\
\hline 9 & $116.8, \mathrm{CH}$ & $6.75, d(9.0)$ & $116.7, \mathrm{CH}$ & $6.73, \mathrm{~d}(9.0)$ \\
\hline 10 & $158.0, \mathrm{C}$ & - & $158.0, \mathrm{C}$ & - \\
\hline 11 & $116.8, \mathrm{CH}$ & $6.75, \mathrm{~d}(9.0)$ & $116.7, \mathrm{CH}$ & $6.73, \mathrm{~d}(9.0)$ \\
\hline 12 & 131.0, $\mathrm{CH}$ & $7.12, \mathrm{~d}(9.0)$ & $131.0, \mathrm{CH}$ & $7.08, \mathrm{~d}(9.0)$ \\
\hline 13 & $163.4, \mathrm{C}$ & - & $163.2, \mathrm{C}$ & - \\
\hline 14 & $52.6, \mathrm{CH}_{3}$ & $3.89, \mathrm{~s}$ & $52.8, \mathrm{CH}_{3}$ & $3.92, \mathrm{~s}$ \\
\hline 15 & $123.2, \mathrm{CH}$ & $7.14, \mathrm{dd}(17.5,11.5)$ & $44.8, \mathrm{CH}$ & $4.51, \mathrm{t}(3.5)$ \\
\hline 16 & 121.0, $\mathrm{CH}_{2}$ & $\begin{array}{l}5.58, \mathrm{dd}(11.5,1.1) \\
5.96, \mathrm{dd}(17.5,1.1)\end{array}$ & $48.9 *, \mathrm{CH}_{2}$ & $3.22, \mathrm{dd}(3.5,1.6)$ \\
\hline
\end{tabular}

Fraction F1 (a mixture of compounds 2 and 4 (ratio 1:2)) was isolated as a yellow oil from both supernatant and mycelial extracts. On the basis of HR-ESIMS and 1D/2D NMR data of this mixture, the structure of compound 4 could be determined independently. HR-ESIMS data revealed the molecular formula of compound 4 as $\mathrm{C}_{14} \mathrm{H}_{13} \mathrm{NO}_{5}$ (9 degrees of unsaturation) provided by the $[\mathrm{M}+\mathrm{H}]^{+}$ion at $\mathrm{m} / \mathrm{z}$ 276.0866 and $[\mathrm{M}+\mathrm{Na}]^{+}$ion at $\mathrm{m} / \mathrm{z}$ 298.0862. Detailed analysis of its 1D and 2D NMR data showed similar features to those of compound 3, except that the olefinic bond C-15 ( $\delta 123.2) / C-16(\delta 121.0)$ was substituted by an epoxide group C-15 $(\delta 44.8) / C-16(\delta 48.9)$. The assumption was evidenced from the established molecular formula and was confirmed not only by the COSY correlation of $\mathrm{H}-15(\delta 4.51)$ to $\mathrm{H}-16(\delta 3.22)$, but also by HMBC correlations of H-16 ( $\delta 3.22)$ to C-15 $(\delta 44.8) / C-5(\delta 155.1)$. Therefore, compound 4 was elucidated unambiguously as methyl 2-(4-hydroxybenzyl)-5-(oxiran-2-yl)-oxazole-4-carboxylate, named macrooxazole D. As can be seen in Figure 1, compounds 2 and 4 are both also present in the crude extract, suggesting they are both genuine natural products and that compound 2 does not only arise from macrooxazole D (4) as an isolation artefact during preparative HPLC separation. However, the conversion could already have taken place during fermentation of the fungus.

For an unambiguous confirmation of its structure, macrocidin $\mathrm{Z}(\mathbf{6})$ was synthesized starting by attaching 6-heptenoic acid (7) to the Evans auxiliary ( $R$ )-benzyl-2-oxazolidinone (Scheme 1) [18]. The resulting imide 8 was deprotonated at the $\alpha$-position with NaHMDS to give an enolate which was quenched with iodomethane. The resulting 9.8:1 mixture of diastereomers was separated by column chromatography to afford the major isomer 9 in $79 \%$ yield. It was converted to the carboxylic acid 10 in $96 \%$ yield by adding $\mathrm{LiOH}$ and $\mathrm{H}_{2} \mathrm{O}_{2}$. The tetramic acid 12 was prepared according to a known protocol $[17,19,20]$ by treatment of commercial Boc-Tyr(Allyl)-OH (11) with Meldrum's acid. Its acylation with carboxylic acid $\mathbf{1 0}$ via the two-step Yoshii-Yoda protocol $[21,22]$ initially afforded 4-O-acyltetramate 13, which was rearranged to the 3-acyltetramic acid 14. A ring-closing metathesis reaction using Grubbs catalyst gave $N$-Boc-protected macrocidin Z 15 with an $E$-selectivity $>99 \%$ in $89 \%$ yield. Macrocidin Z (6) was obtained quantitatively upon removal of the Boc-protection group with TFA in $30 \%$ total yield over seven steps. 


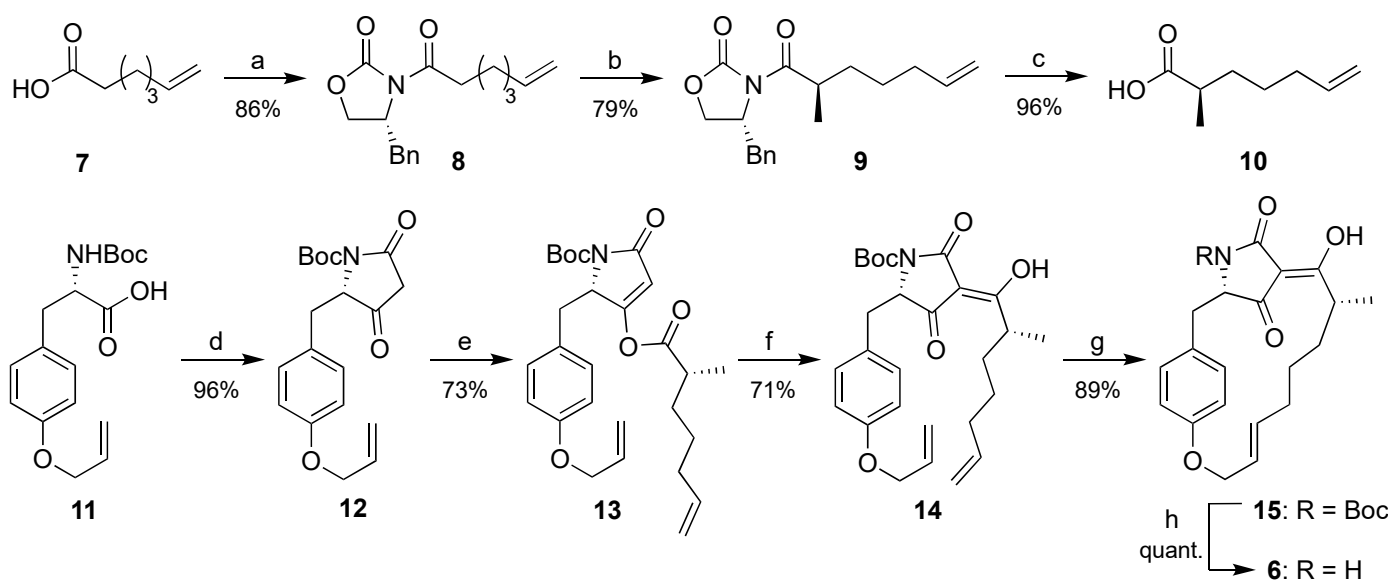

Scheme 1. Synthesis of macrocidin $Z$ (6). Reagents and conditions: (a) DCC, DMAP, (R)-benzyl-2-oxazolidinone, $\mathrm{CH}_{2} \mathrm{Cl}_{2}, 23 \mathrm{~h}$; (b) 1 . NaHMDS, THF, $-78{ }^{\circ} \mathrm{C}, 30 \mathrm{~min}$, 2. MeI, $4.5 \mathrm{~h}$; (c) LiOH, $\mathrm{H}_{2} \mathrm{O}_{2}$, THF/ $\mathrm{H}_{2} \mathrm{O}$ (2:1); (d) Meldrum's acid, DMAP, EDC. $\mathrm{HCl}, \mathrm{CH}_{2} \mathrm{Cl}_{2}$, rt, 2 h; (e) 10, DMAP, EDC.HCl, $\mathrm{CH}_{2} \mathrm{Cl}_{2},{ }^{\circ} \mathrm{C}$, rt, $2 \mathrm{~h}$; (f) $\mathrm{NEt}_{3}, \mathrm{DMAP}, \mathrm{CH}_{2} \mathrm{Cl}_{2}, \mathrm{rt}, 24 \mathrm{~h}$; (g) Grubbs II catalyst, $\mathrm{CH}_{2} \mathrm{Cl}_{2}, \Delta, 15 \mathrm{~h}$; (h) TFA, $\mathrm{CH}_{2} \mathrm{Cl}_{2}, \mathrm{rt}, 15 \mathrm{~min}$. $\mathrm{DCC}=$ dicyclohexylcarbodiimide; DMAP = dimethylaminopyridine; NaHMDS = sodium hexamethyldisilazanide; $\mathrm{THF}=$ tetrahydrofuran; $\mathrm{EDC}=1$-ethyl-3-(3-dimethylaminopropyl)carbodiimide; TFA $=$ trifluoroacetic acid .

\subsection{Biological Activities}

The isolated metabolites were evaluated for their antimicrobial activity against various bacteria and fungi. The Minimum Inhibitory Concentration (MIC) values showed that only the new metabolite 3 as well as the known macrocidins $\mathbf{5}$ and $\mathbf{6}$ were active, whereas the remaining compounds were inactive against the organisms tested (See Table S1 in the supporting information). Macrocidin A (5) showed the strongest activity against Bacillus subtilis with an MIC value of $16.7 \mu \mathrm{g} / \mathrm{mL}$ which is the same value as that of oxytetracyclin used as positive control. The same compound $\mathbf{5}$ demonstrated weak activity against Mycobacterium smegmatis with an MIC value of $33.3 \mu \mathrm{g} / \mathrm{mL}$. Compound 3 exhibited moderate activity against Mucor hiemalis with an MIC value of $66.7 \mu \mathrm{g} / \mathrm{mL}$ equal to that of nystatin used as a positive control. The latter also inhibited the growth of Bacilus subtilis at $66.7 \mu \mathrm{g} / \mathrm{mL}$. Against Micrococcus luteus, compound 6 exhibited weak activity with an MIC value of $66.7 \mu \mathrm{g} / \mathrm{mL}$. Furthermore, the ability of some of the isolated compounds to inhibit the proliferation of two mammalian cell lines including HeLa cells KB3.1 and mouse fibroblasts L929 was examined. Only the mixture of compounds 2 and 4 (ratio 1:2) showed weak cytotoxic activity against HeLa cells KB3.1 and mouse fibroblasts L929 with an $\mathrm{IC}_{50}$ value of $23 \mu \mathrm{g} / \mathrm{mL}$ for both cell lines, whereas compound 5 and $\mathbf{6}$ only showed a slight inhibition of HeLa cells KB3.1 proliferation (See Table S2 in the supporting information).

Moreover, the isolated pure compounds except compound 4 (which was not tested because it was isolated as a mixture) were evaluated for their effectiveness in inhibiting biofilm formation and preformed biofilm of Staphylococcus aureus (Table 4). The new compounds 2 and 3 showed moderate-to-weak activity against biofilm formation, with respective inhibition percentages of $65 \%$ and $75 \%$ at the highest concentration of $250 \mu \mathrm{g} / \mathrm{mL}$. Compounds 5 and 6 inhibited $61 \%$ and $19 \%$ of the bacterial biofilm at $15.6 \mu \mathrm{g} / \mathrm{mL}$, respectively (Figure 5). Interestingly, the test compounds also displayed activity against preformed biofilm of $S$. aureus as represented in Table 4 below. Macrocidins A (5) and Z (6) exhibited moderate activity against preformed biofilm of $S$. aureus with the highest percentage of inhibition of $75 \%$ and $73 \%$ at $250 \mu \mathrm{g} / \mathrm{mL}$, respectively. 


\section{Materials and Methods}

\subsection{General Experimental Procedure}

Electrospray mass (ESIMS) spectra were recorded with an UltiMate 3000 Series uHPLC (Thermo Fischer Scientific, Waltman, MA, USA) utilizing a C18 Acquity UPLC BEH column $(2.1 \times 50 \mathrm{~mm}, 1.7 \mu \mathrm{m}$; Waters, Milford, CT, USA) connected to an amaZon speed ESI-Iontrap-MS (Bruker, Billerica, MA, USA). HPLC parameters were set as follows: solvent $\mathrm{A}: \mathrm{H}_{2} \mathrm{O}+0.1 \%$ formic acid, solvent $\mathrm{B}$ : acetonitrile $(\mathrm{ACN})+0.1 \%$ formic acid, gradient: $5 \% \mathrm{~B}$ for $0.5 \mathrm{~min}$ increasing to $100 \% \mathrm{~B}$ in $19.5 \mathrm{~min}$, then isocratic condition at $100 \% \mathrm{~B}$ for $5 \mathrm{~min}$, a flow rate of $0.6 \mathrm{~mL} / \mathrm{min}$, and diode array detection (DAD) in the range of 190-600 $\mathrm{nm}$.

HR-ESIMS (High-resolution electrospray ionization mass spectrometry) spectra were recorded with an Agilent 1200 Infinity Series HPLC-UV system (Agilent Technologies, Santa Clara, CA, USA) (column $2.1 \times 50 \mathrm{~mm}, 1.7 \mu \mathrm{m}, \mathrm{C} 18$ Acquity UPLC BEH (waters), solvent $\mathrm{A}: \mathrm{H}_{2} \mathrm{O}+0.1 \%$ formic acid; solvent $\mathrm{B}$ : $\mathrm{ACN}+0.1 \%$ formic acid, gradient: $5 \% \mathrm{~B}$ for $0.5 \mathrm{~min}$ increasing to $100 \% \mathrm{~B}$ in $19.5 \mathrm{~min}$ and then maintaining 100\% B for $5 \mathrm{~min}$, flow rate $0.6 \mathrm{~mL} / \mathrm{min}$, UV/Vis detection 200-640 nm) connected to a MaXis ESI-TOF mass spectrometer (Bruker) (scan range 100-2500 m/z, capillary voltage $4500 \mathrm{~V}$, dry temperature $200{ }^{\circ} \mathrm{C}$ ). High-resolution mass spectra of synthetic products were obtained with a UPLC/Orbitrap MS system in ESI mode.

Optical rotations were recorded in methanol (Uvasol, Merck, Darmstadt, Germany) by using an Anton Paar MCP-150 polarimeter (Seelze, Germany) at $25^{\circ} \mathrm{C}$ for isolated compounds, and by using a PerkinElmer 241 polarimeter for synthetic products dissolved in $\mathrm{CHCl}_{3}, \mathrm{MeCN}$ or methanol. UV/Vis spectra were recorded using methanol (Uvasol, Merck, Darmstadt, Germany) with a Shimadzu UV/Vis 2450 spectrophotometer (Kyoto, Japan). ECD spectra were obtained on a J-815 spectropolarimeter (JASCO, Pfungstadt, Germany). Nuclear magnetic resonance (NMR) spectra were recorded with an Avance III 500 spectrometer (Bruker, ${ }^{1} \mathrm{H}-\mathrm{NMR}: 500 \mathrm{MHz}$ and ${ }^{13} \mathrm{C}-\mathrm{NMR}: 125 \mathrm{MHz}$ ). IR spectra were recorded with an FT-IR spectrophotometer equipped with an ATR unit.

For the purification of synthetic products, chromatography silica gel 60 (40-63 $\mu \mathrm{m})$ or silica gel RP18 (40-63 $\mu \mathrm{m})$ were used. Analytical thin-layer chromatography (TLC) was carried out using Merck silica gel $60 \mathrm{~F}_{254}$ pre-coated aluminum-backed plates.

\subsection{Fungal Material}

The fungal strain Phoma macrostoma DAOMC 175,940 was originally isolated from the Canadian thistle Circium arvense collected in Quebec, Canada in 1979. It constitutes one of the original producer strains of the macrocidins $[15,16,23]$ and was kindly provided by the CCFC (Canadian Collection of Fungal Cultures, Ottawa, ON, Canada).

\subsection{Small-Scale Fermentation and Extraction}

The fungus was cultivated in Q6 $\frac{1}{2}$ medium $(10 \mathrm{~g} / \mathrm{mL}$ glycerol, $2.5 \mathrm{~g} / \mathrm{mL}$ D-glucose, $5 \mathrm{~g} / \mathrm{mL}$ cotton seed flour and $\mathrm{pH}=7.2)$ [24]. A well-grown culture from a yeast-malt $(\mathrm{YM})$ agar plate $(10 \mathrm{~g} / \mathrm{mL}$ malt extract, $4 \mathrm{~g} / \mathrm{mL}$ yeast extract, $4 \mathrm{~g} / \mathrm{mL}$ D-glucose, $1.5 \%$ agar and $\mathrm{pH}=6.3$ ) was cut into small pieces using a cork borer $(7 \mathrm{~mm})$, and eight pieces were inoculated into $6 \times 500 \mathrm{~mL}$ Erlenmeyer flasks, each containing $200 \mathrm{~mL}$ of the Q6 $\frac{1}{2}$ medium. The culture was incubated at $23{ }^{\circ} \mathrm{C}$ on a rotary shaker (140 rpm). The growth of the fungus was monitored by measuring the amount of free glucose using Diastix Harnzuckerstreifen (Bayer). After glucose depletion, small samples were taken to monitor secondary metabolite production over a period of 14 days (searching for the mass spectra and UV/Vis spectra that were reported to be typical for the macrocidins) and a stagnation of the titres of the putative macrocidin derivatives was observed by HPLC-MS between 8 and 14 days.

Then, the fermentation was terminated and the supernatant and mycelia were separated by filtration. The supernatant was extracted with equal amount of ethyl acetate $(200 \mathrm{~mL})$ and filtered through anhydrous sodium sulphate. The resulting ethyl acetate extract was evaporated to dryness by 
means of rotary evaporator. The mycelia was extracted with $200 \mathrm{~mL}$ of acetone in an ultrasonic bath at $40{ }^{\circ} \mathrm{C}$ for $40 \mathrm{~min}$, filtered and the filtrate evaporated. The remaining water phase was suspended in equal amount of distilled water and subjected to same procedure as the supernatant.

\subsection{Scale Up of Production in Shake Flask Batches and Extraction}

Four well-grown 17-day-old YM agar plates of the mycelial culture were cut into small pieces using a $7 \mathrm{~mm}$ cork borer and 8 pieces inoculated in $30 \times 500 \mathrm{~mL}$ Erlenmeyer flasks containing $200 \mathrm{~mL}$ of Q6 $\frac{1}{2}$ medium. The culture was incubated at $23{ }^{\circ} \mathrm{C}$ on a rotary shaker $(140 \mathrm{rpm})$ for 13 days. Fermentation was aborted 10 days after the depletion of free glucose.

The mycelia and supernatant from the batch fermentation were separated via filtration. The mycelia was extracted with $4 \times 500 \mathrm{~mL}$ of acetone in an ultrasonic water bath at $40{ }^{\circ} \mathrm{C}$ for $40 \mathrm{~min}$. The extracts were combined and the solvent evaporated by means of a rotary evaporator. The remaining water phase was four times subjected to the same procedure as mycelium in small-scale extraction yielding $949 \mathrm{mg}$ dark brown crude extract. The supernatant (6 L) was extracted with an equal amount of ethyl acetate and filtered through anhydrous sodium sulphate. The resulting ethyl acetate extract was evaporated to dryness by means of rotary evaporator to afford $238 \mathrm{mg}$ of brown crude extract.

\subsection{Isolation of Compounds $\mathbf{1}-\mathbf{6}$}

The mycelial and the supernatant crude extracts from shake flask batch fermentations (3.4) dissolved in methanol were centrifuged by means of a centrifuge (Hettich Rotofix 32 A, Tuttlingen, Germany) for $10 \mathrm{~min}$ at $4000 \mathrm{rpm}$. The extracts were purified separately using preparative reverse-phase liquid chromatography (PLC 2020; Gilson, Middleton, WI, USA). A VP Nucleodur 100-5 C18ec column $(250 \times 21 \mathrm{~mm}, 7 \mu \mathrm{m}$ : Machery-Nagel, Düren, Germany) was used as the stationary phase. Deionized water (Milli-Q, Millipore, Schwalbach, Germany) with 0.1\% formic acid (FA) (solvent A) and acetonitrile $(\mathrm{ACN})$ with $0.1 \% \mathrm{FA}$ (solvent $\mathrm{B}$ ) were used as the mobile phase. The elution gradient used was $5-45 \%$ solvent B for $20 \mathrm{~min}, 45-60 \%$ B for $15 \mathrm{~min}, 60-100 \%$ B for $10 \mathrm{~min}$ and thereafter isocratic condition at $100 \%$ solvent $B$ for $5 \mathrm{~min}$. The flow rate was $15 \mathrm{~mL} / \mathrm{min}$ and the fractions obtained from both the supernatant and mycelial extracts were combined according to UV absorption at 190, 210 and $280 \mathrm{~nm}$ as well as concurrent HPLC-MS analyses to yield compound $\mathbf{1}\left(7.98 \mathrm{mg}, t_{R}: 3.7-3.9 \mathrm{~min}\right)$, 2 (5.20 mg, $\left.t_{R}: 2.3-2.5 \mathrm{~min}\right), 3\left(8.22 \mathrm{mg}, t_{R}: 6.4-6.6 \mathrm{~min}\right), 5\left(39.12 \mathrm{mg}, t_{R}: 7.4-7.6 \mathrm{~min}\right), 6$ (32.10 mg, $t_{R:}$ 9.3-9.5 $\left.\mathrm{min}\right)$ and fraction F1 $(7.20 \mathrm{mg})$, which was a mixture of compounds $2\left(t_{R}: 2.3-2.5 \mathrm{~min}\right)$ and 4 $\left(t_{R}: 4.8-5.0 \mathrm{~min}\right.$ ) with compound 4 as the major component (ratio 1:2).

A total of $5 \mathrm{mg}$ of $\mathrm{F} 1$ was further purified by reversed phase $\mathrm{HPLC}$ (solvent $\mathrm{A}\left(\mathrm{H}_{2} \mathrm{O}+0.1 \%\right.$ FA)/solvent B (ACN + 0.1\% FA)), elution gradient 20-50\% solvent B for 35 min followed by maintaining isocratic condition at $100 \%$ solvent $B$ for 5 min with a preparative HPLC column (VP Nucleodur 100-10 C18ec column $(250 \times 10 \mathrm{~mm}, 7 \mu \mathrm{m}$ : Machery-Nagel, Düren, Germany) as stationary phase $)$ and a flow rate of $8 \mathrm{~mL} / \mathrm{min}$, to afford only compound 2 . The absence of the peak of compound 4 in the obtained HPLC chromatogram suggests the instability of compound 4 which easily turns into compound 2.

\subsection{Physico-Chemical Characteristics of Compounds 1-6}

Methyl 5-(2-Hydroxyethyl)-2-(4-hydroxybenzyl)-oxazole-4-carboxylate (Macrooxazole A (1)): Yellow oil. UV (MeOH, c = $0.025 \mathrm{mg} / \mathrm{mL}) \lambda_{\max }(\log \varepsilon) 202$ (4.15), 227 (4.14), 277 (3.36) nm. HR-ESIMS m/z 300.0837 $[\mathrm{M}+\mathrm{Na}]^{+} ; m / z 555.1968[2 \mathrm{M}+\mathrm{H}]^{+} ; m / z 278.1026[\mathrm{M}+\mathrm{H}]^{+}\left(\right.$Calcd for $\left.\mathrm{C}_{14} \mathrm{H}_{16} \mathrm{NO}_{5} 278.1023\right)$. For NMR data, see Table 2 .

Methyl 5-(1,2-Dihydroxyethyl)-2-(4-hydroxybenzyl)-oxazole-4-carboxylate (Macrooxazole $B$ (2)): Yellow oil. $[\alpha]^{25} \mathrm{D}=0^{\circ}(\mathrm{c}=0.002, \mathrm{MeOH}) ; \mathrm{UV}(\mathrm{MeOH}, \mathrm{c}=0.025 \mathrm{mg} / \mathrm{mL}) \lambda_{\max }(\log \varepsilon) 202(4.15), 227$ (4.12), 278 (3.21) nm. HR-ESIMS m/z 316.0788 [M + Na] ${ }^{+} ; m / z 276.0865\left[\mathrm{M}+\mathrm{H}-\mathrm{H}_{2} \mathrm{O}\right]^{+} ; m / z 294.0974$ $[\mathrm{M}+\mathrm{H}]^{+}\left(\right.$Calcd for $\mathrm{C}_{14} \mathrm{H}_{16} \mathrm{NO}_{6}$ 294.0972). For NMR data, see Table 2. 
Methyl 2-(4-Hydroxybenzyl)-vinyloxazole-4-carboxylate (Macrooxazole C (3)): Brown oil. UV (MeOH, $\mathrm{c}=0.025 \mathrm{mg} / \mathrm{mL}) \lambda_{\max }(\log \varepsilon) 201(4.01), 228(3.96), 272(3.89) \mathrm{nm}$. HR-ESIMS m/z 282.0737 [M + Na] $]^{+}$; $m / z 260.0917[\mathrm{M}+\mathrm{H}]^{+}$(Calcd for $\mathrm{C}_{14} \mathrm{H}_{14} \mathrm{NO}_{4}$ 260.0917). For NMR data, see Table 3.

Methyl 2-(4-Hydroxybenzyl)-5-(oxiran-2-yl)-oxazole-4-carboxylate (macrooxazole D (4)): Yellow oil. UV (MeOH, c $=0.025 \mathrm{mg} / \mathrm{mL}) \lambda_{\max }(\log \varepsilon) 201$ (4.06), 227 (3.96), 274 (3.35) nm. HR-ESIMS m/z 298.0682 [M+ Na] $]^{+} ; m / z 551.1656[2 \mathrm{M}+\mathrm{H}]^{+} ; m / z 276.0866[\mathrm{M}+\mathrm{H}]^{+}\left(\right.$Calcd for $\left.\mathrm{C}_{14} \mathrm{H}_{14} \mathrm{NO}_{5} 276.0866\right)$. For NMR data, see Table 3.

Macrocidin A (5): Beige-yellowish solid. $[\alpha]^{25} \mathrm{D}=+45^{\circ}(\mathrm{c}=0.001, \mathrm{MeOH}) ; \mathrm{UV}(\mathrm{MeOH}, \mathrm{c}=0.025$ $\mathrm{mg} / \mathrm{mL}) \lambda_{\max }(\log \varepsilon) 201$ (4.25), $224(4.16), 281(4.14) \mathrm{nm} ; \mathrm{CD}\left(\mathrm{c}=2.8 \times 10^{-3} \mathrm{M}, \mathrm{MeOH}\right) \lambda_{\max }(\Delta \varepsilon) 218$ (+11.77), $234(-9.41), 274(+8.91)$. HR-ESIMS $m / z 715.3223[2 \mathrm{M}+\mathrm{H}]^{+} ; m / z 340.1547\left[\mathrm{M}+\mathrm{H}-\mathrm{H}_{2} \mathrm{O}\right]^{+}$ $m / z 380.1465[\mathrm{M}+\mathrm{Na}]^{+} ; \mathrm{m} / z 358.1655[\mathrm{M}+\mathrm{H}]^{+}$(Calcd for $\left.\mathrm{C}_{20} \mathrm{H}_{24} \mathrm{NO}_{5} 358.1649\right) .{ }^{1} \mathrm{H}-\mathrm{NMR}(500 \mathrm{MHz}$, MeOH-d4): $\delta_{\mathrm{H}} 6.82(2 \mathrm{H}, \mathrm{d}, J=8.7 \mathrm{~Hz}, \mathrm{H}-3 / \mathrm{H}-21) ; \delta_{\mathrm{H}} 7.04(2 \mathrm{H}, \mathrm{br} \mathrm{d}, J=8.7 \mathrm{~Hz}, \mathrm{H}-4 / \mathrm{H}-22), \delta_{\mathrm{H}} 2.92(1 \mathrm{H}$, $\mathrm{dd}, J=14.1,4.0 \mathrm{~Hz}, \mathrm{H}-6 \mathrm{a}), \delta_{\mathrm{H}} 3.12(1 \mathrm{H}, \mathrm{dd}, J=14.1,3.4 \mathrm{~Hz}, \mathrm{H}-6 \mathrm{~b}), \delta_{\mathrm{H}} 4.11(1 \mathrm{H}, \mathrm{t}, J=3.6 \mathrm{~Hz}, \mathrm{H}-7), \delta_{\mathrm{H}}$ $3.59(1 \mathrm{H}, \mathrm{m}, \mathrm{H}-12), \delta_{\mathrm{H}} 1.46(1 \mathrm{H}, \mathrm{ddd}, J=13.1,11.6,4.1 \mathrm{~Hz}, \mathrm{H}-13 \mathrm{a}), \delta_{\mathrm{H}} 1.36(1 \mathrm{H}, \mathrm{tt}, J=13.1,4.1 \mathrm{~Hz}$, $\mathrm{H}-13 \mathrm{~b}), \delta_{\mathrm{H}} 0.46(1 \mathrm{H}, \mathrm{qt}, J=12.9,4.7 \mathrm{~Hz}, \mathrm{H}-14 \mathrm{a}), \delta_{\mathrm{H}} 1.15(1 \mathrm{H}, \mathrm{qt}, J=13.1,4.1 \mathrm{~Hz}, \mathrm{H}-14 \mathrm{~b}), \delta_{\mathrm{H}} 1.9(1 \mathrm{H}$, $\mathrm{tt}, J=12.8,3.5 \mathrm{~Hz}, \mathrm{H}-15 \mathrm{a}), \delta_{\mathrm{H}} 0.76(1 \mathrm{H}, \mathrm{tdd}, J=12.9,9.8,5.0 \mathrm{~Hz}, \mathrm{H}-15 \mathrm{~b}), \delta_{\mathrm{H}} 3.03(1 \mathrm{H}, \mathrm{ddd}, J=9.9,3.4$, $2.4 \mathrm{~Hz}, \mathrm{H}-16), \delta_{\mathrm{H}} 2.58(1 \mathrm{H}, \mathrm{dt}, J=8.5,2.0 \mathrm{~Hz}, \mathrm{H}-17), \delta_{\mathrm{H}} 4.40(1 \mathrm{H}, \mathrm{dd}, J=12.7,1.8 \mathrm{~Hz}, \mathrm{H}-18 \mathrm{a}), \delta_{\mathrm{H}} 3.95$ $(1 \mathrm{H}, \mathrm{dd}, J=12.7,8.7 \mathrm{~Hz}, \mathrm{H}-18 \mathrm{~b}), \delta_{\mathrm{H}} 1.08(3 \mathrm{H}, \mathrm{d}, J=6.9 \mathrm{~Hz}, \mathrm{H}-20) .(3 \mathrm{H}, \mathrm{d}, J=6.9 \mathrm{~Hz}, \mathrm{H}-20)$.

Macrocidin Z (6): Yellow oil. $[\alpha]^{25} \mathrm{D}=+123.5^{\circ}(\mathrm{c}=0.00942, \mathrm{MeOH}) ; \mathrm{UV}(\mathrm{MeOH}, \mathrm{c}=0.025$ $\mathrm{mg} / \mathrm{mL}) \lambda_{\max }(\log \varepsilon) 201$ (4.11), 226 (3.92), $281(3.90) \mathrm{nm} ; \mathrm{CD}\left(\mathrm{c}=2.9 \times 10^{-3} \mathrm{M}, \mathrm{MeOH}\right) \lambda_{\max }(\Delta \varepsilon) 219$ (+7.67), 237 (-4.87), 274 (+9.36). HR-ESIMS $m / z$ 683.3324 [2M + H] $]^{+} ; m / z 342.1701[\mathrm{M}+\mathrm{H}]^{+}($Calcd for $\mathrm{C}_{20} \mathrm{H}_{24} \mathrm{NO}_{4}$ 342.1700). For NMR data, see Table 2.

\subsection{Synthesis of Macrocidin Z (6)}

(R)-4-Benzyl-3-(hept-6-enoyl)oxazolidin-2-one (8) [25]: 6-Heptenoic acid (7; $100 \mu \mathrm{L}, 738 \mu \mathrm{mol})$ in dry $\mathrm{CH}_{2} \mathrm{Cl}_{2}(1 \mathrm{~mL})$ at $0{ }^{\circ} \mathrm{C}$ was treated with DMAP (dimethylaminopyridine; $8.20 \mathrm{mg}, 738 \mu \mathrm{mol}$ ), (R)-benzyl-2-oxazolidinone (119 mg, $671 \mu \mathrm{mol}$ ) and DCC (dicyclohexylcarbodiimide; $152 \mathrm{mg}, 738 \mu \mathrm{mol}$ ). The mixture was stirred for $23 \mathrm{~h}$ at room temperature. The white precipitate was filtered off and washed with $\mathrm{CH}_{2} \mathrm{Cl}_{2}$. The filtrate was washed with aqueous sat. $\mathrm{NaHCO}_{3}$ solution and the aqueous phase was extracted with $\mathrm{CH}_{2} \mathrm{Cl}_{2}(2 \times 20 \mathrm{~mL})$. The combined organic phases were dried over $\mathrm{Na}_{2} \mathrm{SO}_{4}$. After removing the solvent under reduced pressure, the crude product was purified by silica gel column chromatography on silica gel 60 using a mobile phase of $12.5 \%$ ethyl acetate (EtOAc in hexane, to give imide $8(166 \mathrm{mg}, 86 \%)$ as a colorless oil; $\mathrm{R}_{\mathrm{f}}=0.68\left(25 \%\right.$ EtOAc in hexanes); ${ }^{1} \mathrm{H}-\mathrm{NMR}\left(500 \mathrm{MHz}, \mathrm{CDCl}_{3}\right)$ $\delta 1.49$ (quin, $J=7.6 \mathrm{~Hz}, 2 \mathrm{H}), 1.74(\mathrm{~m}, 2 \mathrm{H}), 2.11(\mathrm{~m}, 2 \mathrm{H}), 2.77(\mathrm{dd}, J=13.3,9.6 \mathrm{~Hz}, 1 \mathrm{H}), 2.95(\mathrm{~m}, 2 \mathrm{H})$, $3.30(\mathrm{dd}, J=13.3,3.3 \mathrm{~Hz}, 1 \mathrm{H}), 4.19(\mathrm{~m}, 2 \mathrm{H}), 4.67(\mathrm{~m}, 1 \mathrm{H}), 4.97(\mathrm{~m}, 1 \mathrm{H}), 5.03(\mathrm{dq}, J=17.2,1.5 \mathrm{~Hz}, 1 \mathrm{H})$, $5.82(\mathrm{~m}, 1 \mathrm{H}), 7.19-7.36(\mathrm{~m}, 5 \mathrm{H}) ;{ }^{13} \mathrm{C}-\mathrm{NMR}\left(125 \mathrm{MHz}, \mathrm{CDCl}_{3}\right) \delta 23.8,28.4,33.6,35.5,38.1,55.3,66.3$, $114.9,127.5,129.1,129.6,135.4,138.6,153.6,173.4$.

$(R, R)-4-B e n z y l-3-(2-m e t h y l h e p t-6-e n o y l) o x a z o l i d i n-2-o n e(9)$ : A solution of imide 8 (1.32 g, $4.60 \mathrm{mmol})$ in dry THF $(11 \mathrm{~mL})$ at $-78{ }^{\circ} \mathrm{C}$ was treated with $1 \mathrm{M}$ NaHMDS in THF $(5.29 \mathrm{~mL}, 5.29 \mathrm{mmol})$, stirred for $30 \mathrm{~min}$, and then quenched with iodomethane $(1.50 \mathrm{~mL}, 24.0 \mathrm{mmol})$. The resulting mixture was stirred for $4.5 \mathrm{~h}$, diluted with $\mathrm{H}_{2} \mathrm{O}(100 \mathrm{~mL})$, and the aqueous phase was extracted with $\mathrm{Et}_{2} \mathrm{O}(3 \times 75 \mathrm{~mL})$. The combined organic phases were dried over $\mathrm{Na}_{2} \mathrm{SO}_{4}$ and concentrated under reduced pressure to give a crude product which was purified by column chromatography (silica gel 60, 10\% EtOAc in hexanes) to leave $9(1.10 \mathrm{~g}, 79 \%)$ as a colorless oil; $R_{\mathrm{f}}=0.72\left(25 \%\right.$ EtOAc in hexanes); $[\alpha]^{24}{ }^{-}-61.6$ (c 1.46, $\mathrm{CHCl}_{3}$ ); IR $v_{\max } 3079(\mathrm{w}), 3024(\mathrm{w}), 2974(\mathrm{w}), 2932(\mathrm{~m}), 2857(\mathrm{w}), 1779(\mathrm{~s}), 1697(\mathrm{~s}), 1455(\mathrm{w}), 1385(\mathrm{~m})$, $1350(\mathrm{~m}), 1240(\mathrm{~m}), 1211(\mathrm{~m}), 1196(\mathrm{~m}), 1101(\mathrm{w}), 913$ (w), $703(\mathrm{~m}) \mathrm{cm}^{-1} ;{ }^{1} \mathrm{H}-\mathrm{NMR}\left(500 \mathrm{MHz}, \mathrm{CDCl}_{3}\right)$ $\delta 1.23(\mathrm{~d}, J=6.88 \mathrm{~Hz}, 3 \mathrm{H}), 1.43(\mathrm{~m}, 3 \mathrm{H}), 1.76(\mathrm{~m}, 1 \mathrm{H}), 2.01(\mathrm{~m}, 2 \mathrm{H}), 2.77(\mathrm{dd}, J=13.2,9.5 \mathrm{~Hz}, 1 \mathrm{H})$, $3.27(\mathrm{dd}, J=13.3,3.1 \mathrm{~Hz}, 1 \mathrm{H}), 3.72(\mathrm{~m}, 1 \mathrm{H}), 4.19(\mathrm{~m}, 2 \mathrm{H}), 4.67(\mathrm{~m}, 1 \mathrm{H}), 4.95(\mathrm{~m}, 1 \mathrm{H}), 5.01(\mathrm{dq}, J=17.2$, $1.7 \mathrm{~Hz}, 1 \mathrm{H}), 5.79(\mathrm{~m}, 1 \mathrm{H}), 7.19-7.36(\mathrm{~m}, 5 \mathrm{H}) ;{ }^{13} \mathrm{C}-\mathrm{NMR}\left(125 \mathrm{MHz}, \mathrm{CDCl}_{3}\right) \delta$ 17.5, 26.6, 33.0, 33.8, 37.7, 
38.0, 55.5, 66.1, 114.8, 127.5, 129.0, 129.6, 135.4, 138.6, 153.2, 177.3; HRMS (ESI): $m / z\left[\mathrm{C}_{18} \mathrm{H}_{23} \mathrm{NO}_{3}+\mathrm{H}^{+}\right]$: calcd 302.17507, found 302.17438 .

(R)-2-Methylhept-6-enoic acid (10): A solution of imide $9(1.20 \mathrm{~g}, 3.98 \mathrm{mmol})$ in THF (36 mL) and $\mathrm{H}_{2} \mathrm{O}(16 \mathrm{~mL})$ was treated with $\mathrm{LiOH} \mathrm{H}_{2} \mathrm{O}(334 \mathrm{mg}, 7.96 \mathrm{mmol})$ and $\mathrm{H}_{2} \mathrm{O}_{2}(30 \mathrm{wt} \%, 2.03 \mathrm{~mL}, 19.9 \mathrm{mmol})$ at $0{ }^{\circ} \mathrm{C}$. After stirring at room temperature for $1 \mathrm{~d}$, sat. aqueous $\mathrm{NaHCO}_{3}$ solution $(50 \mathrm{~mL})$ was added, the aqueous layer was extracted with $\mathrm{CH}_{2} \mathrm{Cl}_{2}(50 \mathrm{~mL})$, acidified with $1 \mathrm{M} \mathrm{HCl}$ to $\mathrm{pH}=2$, and extracted with $\mathrm{Et}_{2} \mathrm{O}(3 \times 40 \mathrm{~mL})$. The combined organic phases were dried over $\mathrm{Na}_{2} \mathrm{SO}_{4}$, and concentrated under reduced pressure to give 4 (546 mg, 96\%) as a colorless liquid; $\mathrm{R}_{\mathrm{f}}=0.37$ (25\% EtOAc in hexanes); $[\alpha]^{24} \mathrm{D}-17.4\left(\mathrm{c} 0.69, \mathrm{CHCl}_{3}\right)$; IR $v_{\max } 2978(\mathrm{~m}), 2936(\mathrm{~m}), 2867(\mathrm{~m}), 1706(\mathrm{~s}), 1466(\mathrm{w}), 1414(\mathrm{w}), 1233(\mathrm{~m})$, $992(\mathrm{w}), 911(\mathrm{~m}) \mathrm{cm}^{-1} ;{ }^{1} \mathrm{H}-\mathrm{NMR}\left(500 \mathrm{MHz}, \mathrm{CDCl}_{3}\right) \delta 1.19(\mathrm{~d}, J=5.9 \mathrm{~Hz}, 3 \mathrm{H}), 1.44(\mathrm{~m}, 3 \mathrm{H}), 1.69(\mathrm{~m}, 1 \mathrm{H})$, $2.06(\mathrm{~m}, 2 \mathrm{H}), 2.47(\mathrm{~m}, 1 \mathrm{H}), 4.95(\mathrm{~d}, J=5.0 \mathrm{~Hz}, 1 \mathrm{H}), 5.01(\mathrm{~d}, J=5.0 \mathrm{~Hz}, 1 \mathrm{H}), 5.79(\mathrm{~m}, 1 \mathrm{H}), 11.5(\mathrm{br}, 1 \mathrm{H}$, $\mathrm{OH}) ;{ }^{13} \mathrm{C}-\mathrm{NMR}\left(125 \mathrm{MHz}, \mathrm{CDCl}_{3}\right) \delta$ 17.0, 26.5, 33.1, 33.7, 39.3, 114.9, 138.5, 183.1; HRMS (ESI): mboxemphm $/ z\left[\mathrm{C}_{8} \mathrm{H}_{14} \mathrm{O}_{2}+\mathrm{H}^{+}\right]$: calcd 143.10666, found 143.10656.

(S)-tert-Butyl-2-(4-(allyloxy)benzyl)-3,5-dioxopyrrolidin-1-carboxylate (12) [17]: A solution of Boc-Tyr(Allyl)-OH (11; $1.28 \mathrm{~g}, 3.99 \mathrm{mmol})$ in dry $\mathrm{CH}_{2} \mathrm{Cl}_{2}(13 \mathrm{~mL})$ was treated with Meldrum's acid (633 mg, $4.39 \mathrm{mmol})$, DMAP (683 mg, $5.59 \mathrm{mmol}$ ) and 1-ethyl-3-(3-dimethylaminopropyl)carbodiimide (EDC)-. $\mathrm{HCl}(918 \mathrm{mg}, 4.79 \mathrm{mmol})$ at room temperature. The mixture was stirred for $2 \mathrm{~h}$, concentrated under reduced pressure, and the resulting crude product was diluted with EtOAc $(100 \mathrm{~mL})$ and washed with $0.5 \mathrm{M} \mathrm{H}_{2} \mathrm{SO}_{4}(3 \times 40 \mathrm{~mL})$. The combined aqueous phases were extracted with EtOAc $(2 \times 50 \mathrm{~mL})$. The combined organic phases were washed with $\mathrm{H}_{2} \mathrm{O}(100 \mathrm{~mL})$, dried over $\mathrm{Na}_{2} \mathrm{SO}_{4}$ and refluxed until gas formation ceased. The solvent was removed under reduced pressure to give $\mathbf{1 2}(1.32 \mathrm{~g}, 96 \%)$ as a yellow foam; $R_{f}=0.63\left(10 \% \mathrm{MeOH}\right.$ in $\left.\mathrm{CH}_{2} \mathrm{Cl}_{2}\right)$; IR $v_{\max } 2976(\mathrm{w}), 1755(\mathrm{~m}), 1711(\mathrm{~m}), 1610(\mathrm{~m})$, $1510(\mathrm{~m}), 1364(\mathrm{~m}), 1298(\mathrm{~m}), 1240(\mathrm{~s}), 1149(\mathrm{~s}), 1077(\mathrm{~m}), 1021(\mathrm{~m}), 997(\mathrm{~m}), 925(\mathrm{w}), 829(\mathrm{~m}), 813(\mathrm{~m})$, $788(\mathrm{w}), 772(\mathrm{w}), 756(\mathrm{w}), 656(\mathrm{w}) \mathrm{cm}^{-1}$; ${ }^{1} \mathrm{H}-\mathrm{NMR}\left(500 \mathrm{MHz}, \mathrm{CD}_{3} \mathrm{OD}\right) \delta 1.61(\mathrm{~s}, 9 \mathrm{H}), 3.10(\mathrm{dd}, J=14.2$, $2.6 \mathrm{~Hz}, 1 \mathrm{H}), 3.41(\mathrm{dd}, J=14.2,5.3 \mathrm{~Hz}, 1 \mathrm{H}), 4.47(\mathrm{dt}, J=5.2,1.6 \mathrm{~Hz}, 2 \mathrm{H}), 4.64(\mathrm{dd}, J=5.3,2.6 \mathrm{~Hz}$, $1 \mathrm{H}), 5.22(\mathrm{dq}, J=10.5,1.6 \mathrm{~Hz}, 1 \mathrm{H}), 5.37(\mathrm{dq}, J=17.5,1.6 \mathrm{~Hz}, 1 \mathrm{H}), 6.03(\mathrm{ddt}, J=17.5,10.5,5.2 \mathrm{~Hz}, 1 \mathrm{H})$, $6.78(\mathrm{~m}, 2 \mathrm{H}), 6.97(\mathrm{~m}, 2 \mathrm{H}) ;{ }^{13} \mathrm{C}-\mathrm{NMR}\left(125 \mathrm{MHz}, \mathrm{CD}_{3} \mathrm{OD}\right) \delta 28.5,35.0,62.2,69.7,83.9,115.3,117.3,127.5$, $131.9,135.0,150.9,159.3,173.4,178.2$.

(2S)-tert-Butyl-2-(4-(allyloxy)benzyl)-3-(((R)-2-methylhept-6-enoyl)oxy)-5-oxopyrrolidine-1-carboxylate (13): A stirred solution of carboxylic acid $10(397 \mathrm{mg}, 2.79 \mathrm{mmol})$ in dry $\mathrm{CH}_{2} \mathrm{Cl}_{2}(14 \mathrm{~mL})$ at $0{ }^{\circ} \mathrm{C}$ was treated with EDC HCl $(642 \mathrm{mg}, 3.35 \mathrm{mmol})$ and DMAP $(68.2 \mathrm{mg}, 558 \mu \mathrm{mol})$, allowed to warm to room temperature and stirred for $30 \mathrm{~min}$. The resulting mixture was treated with tetramic acid $\mathbf{1 2}$ $(1.16 \mathrm{~g}, 3.35 \mathrm{mmol})$, stirred for a further $4 \mathrm{~h}$, and then diluted with $0.5 \mathrm{M} \mathrm{H}_{2} \mathrm{SO}_{4}(200 \mathrm{~mL})$. The aqueous phase was extracted with EtOAc $(3 \times 50 \mathrm{~mL})$ and the combined organic phases were washed with brine and dried over $\mathrm{Na}_{2} \mathrm{SO}_{4}$. After the removal of the solvent under reduced pressure, the crude product was purified by column chromatography (silica gel 60, 10\% EtOAc in hexanes $\rightarrow 15 \%$ EtOAc in hexanes $\rightarrow 20 \%$ EtOAc in hexanes $\rightarrow 25 \%$ EtOAc in hexanes $\rightarrow 100 \%$ EtOAc) to afford 13 (967mg, $73 \%)$ as a yellowish oil; $R_{f}=0.93\left(40 \%\right.$ EtOAc in hexanes); $[\alpha]^{24}{ }_{\mathrm{D}} 90.3\left(c 1.15, \mathrm{CHCl}_{3}\right) ; \mathrm{IR} v_{\max } 2971$ (w), $2938(\mathrm{w}), 1781(\mathrm{~m}), 1742(\mathrm{~s}), 1631(\mathrm{~m}), 1512(\mathrm{~m}), 1368(\mathrm{~m}), 1322(\mathrm{~m}), 1229(\mathrm{~m}), 1217(\mathrm{~m}), 1175(\mathrm{~m})$, $1063(\mathrm{~m}), 912(\mathrm{w}), 847(\mathrm{w}) \mathrm{cm}^{-1},{ }^{1} \mathrm{H}-\mathrm{NMR}\left(500 \mathrm{MHz}^{\mathrm{C}} \mathrm{CDCl}_{3}\right) \delta 1.25(\mathrm{t}, J=6.9 \mathrm{~Hz}, 3 \mathrm{H}), 1.43-1.57(\mathrm{~m}, 3 \mathrm{H})$, $1.60(\mathrm{~s}, 9 \mathrm{H}), 1.76(\mathrm{~m}, 1 \mathrm{H}), 2.10(\mathrm{~m}, 2 \mathrm{H}), 2.62(\mathrm{~m}, 1 \mathrm{H}), 3.11(\mathrm{dd}, J=14.2,2.6 \mathrm{~Hz}, 1 \mathrm{H}), 3.36(\mathrm{dd}, J=14.2$, $6.0 \mathrm{~Hz}, 1 \mathrm{H}), 4.48(\mathrm{~m}, 2 \mathrm{H}), 4.77(\mathrm{~m}, 1 \mathrm{H}), 5.00(\mathrm{dd}, J=10.4,1 \mathrm{H}), 5.04(\mathrm{~d}, J=17.2,1 \mathrm{H}), 5.27(\mathrm{~d}, J=10.4$, $1 \mathrm{H}), 5.39(\mathrm{~d}, J=17.2,1 \mathrm{H}), 5.80(\mathrm{~m}, 1 \mathrm{H}), 6.03(\mathrm{~m}, 1 \mathrm{H}), 6.77(\mathrm{~m}, 2 \mathrm{H}), 6.90(\mathrm{~m}, 2 \mathrm{H}) ;{ }^{13} \mathrm{C}-\mathrm{NMR}(125 \mathrm{MHz}$, $\left.\mathrm{CDCl}_{3}\right) \delta 16.8,16.4,28.3,32.8,33.6,34.8,40.0,60.7,68.9,83.2,108.3,114.8,115.4,117.8,126.0,130.5$, $133.3,138.0,149.4,157.9,165.1,168.2,171.9$ [some peaks are doubled due to 13 partially rearranging to 14 on silica gel]; HRMS (ESI): $m / z\left[\mathrm{C}_{27} \mathrm{H}_{35} \mathrm{NO}_{6}+\mathrm{Na}^{+}\right]$: calcd 492.23566, found 492.23499.

(S,Z)-tert-Butyl-2-(4-(allyloxy)benzyl)-4-(1-hydroxy-(2R)-methylhept-6-en-1-ylidene)-3,5-dioxopyrrolidine-1-carboxylate (14): A solution of $13(967 \mathrm{mg}, 2.05 \mathrm{mmol})$ in dry $\mathrm{CH}_{2} \mathrm{Cl}_{2}(20 \mathrm{~mL})$ was treated with $\mathrm{NEt}_{3}(344 \mu \mathrm{L}$, $2.46 \mathrm{mmol})$ and DMAP $(125 \mathrm{mg}, 1.03 \mathrm{mmol})$ and stirred at room temperature for $7 \mathrm{~h}$. DMAP $(62.6 \mathrm{mg}$, $0.51 \mathrm{mmol}$ ) was added and the stirring continued for $16 \mathrm{~h}$. The reaction was quenched with sat. 
aqueous $\mathrm{NaHCO}_{3}$ solution $(100 \mathrm{~mL})$, the aqueous phase was extracted with EtOAc $(3 \times 50 \mathrm{~mL})$, and the combined organic phases were washed with brine and dried over $\mathrm{Na}_{2} \mathrm{SO}_{4}$. The solvent was removed under reduced pressure and the remainder was purified by column chromatography on reversed phase silica gel (RP18, $40 \% \mathrm{MeCN}$ in $\mathrm{H}_{2} \mathrm{O}+0.01 \% \mathrm{HCOOH} \rightarrow 60 \% \mathrm{MeCN}$ in $\mathrm{H}_{2} \mathrm{O}+$ $0.01 \% \mathrm{HCOOH} \rightarrow 80 \% \mathrm{MeCN}$ in $\mathrm{H}_{2} \mathrm{O}+0.01 \% \mathrm{HCOOH} \rightarrow 100 \% \mathrm{MeCN}+0.01 \% \mathrm{HCOOH}$ ) to yield $14(684 \mathrm{mg}, 71 \%)$ as a yellow oil; $R_{f}=0.94\left(10 \% \mathrm{MeOH}\right.$ in $\left.\mathrm{CH}_{2} \mathrm{Cl}_{2}\right) ;[\alpha]^{24} \mathrm{D}^{-26.9}($ c 2.12, $\mathrm{MeOH})$; IR $v_{\max } 3463(\mathrm{w}), 3016(\mathrm{~m}), 2970(\mathrm{~m}), 2945(\mathrm{~m}), 1738(\mathrm{~s}), 1599(\mathrm{w}), 1510(\mathrm{w}), 1366(\mathrm{~s}), 1229(\mathrm{~s}), 1217(\mathrm{~s})$, $1206(\mathrm{~s}), 1156(\mathrm{w}), 907(\mathrm{~m}), 787(\mathrm{w}) \mathrm{cm}^{-1},{ }^{1} \mathrm{H}-\mathrm{NMR}\left(500 \mathrm{MHz}, \mathrm{CD}_{3} \mathrm{OD}\right) \delta 1.01(\mathrm{~m}, 3 \mathrm{H}), 1.23(\mathrm{~m}, 1 \mathrm{H})$, $1.28-1.42(\mathrm{~m}, 2 \mathrm{H}), 1.63(\mathrm{~m}, 1 \mathrm{H}), 1.63(\mathrm{~s}, 9 \mathrm{H}), 2.04(\mathrm{q}, J=6.7 \mathrm{~Hz}, 2 \mathrm{H}), 3.19(\mathrm{dd}, J=14.2,2.7 \mathrm{~Hz}, 1 \mathrm{H})$, $3.38(\mathrm{dd}, J=14.2,5.3 \mathrm{~Hz}, 1 \mathrm{H}), 3.56(\mathrm{~m}, 1 \mathrm{H}), 4.47(\mathrm{~m}, 2 \mathrm{H}), 4.58(\mathrm{br}, 1 \mathrm{H}), 4.95(\mathrm{~m}, 1 \mathrm{H}), 5.01(\mathrm{dq}, J=17.0$, $1.7 \mathrm{~Hz}, 1 \mathrm{H}), 5.21(\mathrm{dq}, J=10.6,1.6 \mathrm{~Hz}, 1 \mathrm{H}), 5.35(\mathrm{dq}, J=17.3,1.6 \mathrm{~Hz}, 1 \mathrm{H}), 5.78(\mathrm{ddt}, J=17.0,10.3,6.7 \mathrm{~Hz}$, $1 \mathrm{H}), 6.03(\mathrm{ddt}, J=17.3,10.6,5.2 \mathrm{~Hz}, 1 \mathrm{H}), 6.76(\mathrm{~m}, 2 \mathrm{H}), 6.90(\mathrm{~m}, 2 \mathrm{H}) ;{ }^{13} \mathrm{C}-\mathrm{NMR}\left(125 \mathrm{MHz}, \mathrm{CD}_{3} \mathrm{OD}\right) \delta$ 17.3, 27.4, 28.4, 33.7, 34.7, 35.8, 37.9, 69.7, 84.9, 115.3, 115.5, 117.4, 127.4, 131.9, 134.8, 139.5, 159.3, 195.1; ${ }^{1} \mathrm{H}-\mathrm{NMR}\left(500 \mathrm{MHz}, \mathrm{CDCl}_{3}\right) \delta 0.91 / 1.13(\mathrm{~d}, J=6.9 \mathrm{~Hz}, 3 \mathrm{H}), 1.15-1.44(\mathrm{~m}, 3 \mathrm{H}), 1.59(\mathrm{~m}, 1 \mathrm{H}), 1.62(\mathrm{~s}, 9 \mathrm{H})$, $2.02(\mathrm{~m}, 2 \mathrm{H}), 3.20 / 3.26(\mathrm{dd}, J=13.8,2.0 \mathrm{~Hz}, 1 \mathrm{H}), 3.34 / 3.40(\mathrm{dd}, J=13.8,5.6 \mathrm{~Hz}, 1 \mathrm{H}), 3.48 / 3.65(\mathrm{~m}, 1 \mathrm{H})$, 4.38/4.63 (m, 1H), $4.44(\mathrm{~m}, 2 \mathrm{H}), 4.88-5.06(\mathrm{~m}, 2 \mathrm{H}), 5.22-5.41(\mathrm{~m}, 2 \mathrm{H}), 5.75(\mathrm{~m}, 1 \mathrm{H}), 6.01(\mathrm{~m}, 1 \mathrm{H})$, $6.73(\mathrm{~m}, 2 \mathrm{H}), 6.91(\mathrm{~m}, 2 \mathrm{H}) ;{ }^{13} \mathrm{C}-\mathrm{NMR}\left(125 \mathrm{MHz}, \mathrm{CDCl}_{3}\right) \delta 17.1 / 17.4,26.5 / 26.6,28.2 / 28.3,32.2 / 33.3,33.8$, 34.9/35.0, 36.3/37.6, 61.8/65.7, 68.7/68.8, 83.4/84.1, 102.1/105.1, 114.7, 114.8/115.1, 117.7/117.8, 126.0/126.4, 130.7/130.9, 133.3, 138.4/138.5, 149.0/150.0, 157.8/157.9, 164.2/173.8, 192.3, 195.6, 197.3, 200.8 [not all quaternary C-atoms are visible in the JMOD in $\mathrm{CD}_{3} \mathrm{OD}$; some of them can be seen via HSQC or HMBC correlations. Some peaks in the ${ }^{1} \mathrm{H}-\mathrm{NMR}$ and JMOD in $\mathrm{CDCl}_{3}$ are doubled because of tautomers]; HRMS (ESI): $m / z\left[\mathrm{C}_{27} \mathrm{H}_{35} \mathrm{NO}_{6}+\mathrm{Na}^{+}\right]$: calcd 492.23566, found 492.23450.

$\mathrm{N}$-Boc-Macrocidin Z (15): A solution of diene $14(634 \mathrm{mg}, 1.35 \mathrm{mmol})$ in degassed $\mathrm{CH}_{2} \mathrm{Cl}_{2}$ $(270 \mathrm{~mL})$ was treated with 2nd generation Grubbs catalyst $(57.3 \mathrm{mg}, 67.5 \mu \mathrm{mol})$ and heated at reflux for $16 \mathrm{~h}$. The solvent was removed under reduced pressure and the remainder was purified by column chromatography on reversed phase silica gel (RP18, $40 \% \mathrm{MeCN}$ in $\mathrm{H}_{2} \mathrm{O}+0.01 \% \mathrm{HCOOH}$ $\rightarrow 60 \% \mathrm{MeCN}$ in $\mathrm{H}_{2} \mathrm{O}+0.01 \% \mathrm{HCOOH} \rightarrow 80 \% \mathrm{MeCN}$ in $\mathrm{H}_{2} \mathrm{O}+0.01 \% \mathrm{HCOOH}$ ) to yield 15 (529 $\mathrm{mg}, 89 \%)$ as a brownish foam; $R_{f}=0.94\left(10 \% \mathrm{MeOH}\right.$ in $\left.\mathrm{CH}_{2} \mathrm{Cl}_{2}\right) ;[\alpha]^{24}{ }_{\mathrm{D}} 155.8(\mathrm{c} 0.62, \mathrm{MeOH}) ; \mathrm{IR}$ $v_{\max } 3456(\mathrm{~m}), 3016(\mathrm{~m}), 2970(\mathrm{~s}), 2944(\mathrm{~m}), 2136(\mathrm{w}), 1740(\mathrm{~s}), 1728(\mathrm{~s}), 1600(\mathrm{~m}), 1436(\mathrm{~m}), 1366(\mathrm{~s})$, 1354 (s), 1299 (m), 1228 (s), 1216 (s), 1296 (m), 1091 (w), $974(\mathrm{w}), 908$ (m), $730(\mathrm{w}), 786(\mathrm{w}) \mathrm{cm}^{-1}$;. ${ }^{1} \mathrm{H}-\mathrm{NMR}\left(500 \mathrm{MHz}, \mathrm{CD}_{3} \mathrm{OD}\right) \delta 0.91(\mathrm{~m}, 1 \mathrm{H}), 1.08(\mathrm{~d}, J=6.7 \mathrm{~Hz}, 3 \mathrm{H}), 1.14(\mathrm{~m}, 2 \mathrm{H}), 1.40(\mathrm{~m}, 1 \mathrm{H})$, $1.63(\mathrm{~s}, 9 \mathrm{H}), 1.82(\mathrm{~m}, 1 \mathrm{H}), 2.11(\mathrm{~m}, 1 \mathrm{H}), 3.07(\mathrm{dd}, J=14.3,3.5 \mathrm{~Hz}, 1 \mathrm{H}), 3.36(\mathrm{dd}, J=14.3,3.1 \mathrm{~Hz}, 1 \mathrm{H})$, $3.47(\mathrm{~m}, 1 \mathrm{H}), 4.46(\mathrm{~m}, 1 \mathrm{H}), 4.54(\mathrm{~m}, 1 \mathrm{H}), 4.65(\mathrm{dd}, J=13.4,9.1 \mathrm{~Hz}, 1 \mathrm{H}), 5.27(\mathrm{~m}, 1 \mathrm{H}), 5.69(\mathrm{~m}, 1 \mathrm{H})$, 6.60-6.97 (m, 4H); ${ }^{13} \mathrm{C}-\mathrm{NMR}\left(125 \mathrm{MHz}, \mathrm{CD}_{3} \mathrm{OD}\right) \delta$ 15.0, 27.7, 28.3, 33.2, 34.8, 35.6, 37.1, 66.8, 67.9, 85.3, 102.9, 115.6, 119.0, 126.8, 130.8, 132.6, 138.8, 157.6, 174.9, 192.4, 193.8, ${ }^{1} \mathrm{H}-\mathrm{NMR}\left(500 \mathrm{MHz}, \mathrm{CDCl}_{3}\right) \delta$ $0.89(\mathrm{~m}, 1 \mathrm{H}), 1.07(\mathrm{~d}, J=6.7 \mathrm{~Hz}, 3 \mathrm{H}), 1.13(\mathrm{~m}, 2 \mathrm{H}), 1.32(\mathrm{~m}, 1 \mathrm{H}), 1.63(\mathrm{~s}, 9 \mathrm{H}), 1.82(\mathrm{~m}, 1 \mathrm{H}), 2.05(\mathrm{~m}, 1 \mathrm{H})$, $3.12(\mathrm{dd}, J=14.3,3.5 \mathrm{~Hz}, 1 \mathrm{H}), 3.37(\mathrm{dd}, J=14.3,3.1 \mathrm{~Hz}, 1 \mathrm{H}), 3.50(\mathrm{~m}, 1 \mathrm{H}), 4.41(\mathrm{t}, J=3.4 \mathrm{~Hz}, 1 \mathrm{H})$, $4.59(\mathrm{~d}, J=6.2 \mathrm{~Hz}, 2 \mathrm{H}), 5.26(\mathrm{dt}, J=15.5,6.2 \mathrm{~Hz}, 1 \mathrm{H}), 5.58(\mathrm{~m}, 1 \mathrm{H}), 6.59-7.01(\mathrm{~m}, 4 \mathrm{H}) ;{ }^{13} \mathrm{C}-\mathrm{NMR}$ $\left(125 \mathrm{MHz}, \mathrm{CDCl}_{3}\right) \delta 13.77 / 14.97,26.3 / 26.6,28.3 / 28.4,32.2 / 33.3,33.9,34.2 / 34.6 / 34.9,35.6 / 37.1,61.7 / 65.7$, 67.3/67.7, 84.3, 102.6, 114.5, 118.5, 125.3/125.5, 125.7, 130.0, 131.6, 135.0/137.6, 148.9, 156.0, 174.1, 191.9, 195.4 [not all quaternary C-atoms are visible in the JMOD in $\mathrm{CD}_{3} \mathrm{OD}$, some of them can be seen via HSQC or HMBC correlations. Some peaks in the ${ }^{1} \mathrm{H}-\mathrm{NMR}$ and JMOD in $\mathrm{CDCl}_{3}$ are doubled because of tautomers]; HRMS (ESI): $m / z\left[\mathrm{C}_{25} \mathrm{H}_{31} \mathrm{NO}_{6}+\mathrm{Na}^{+}\right]$: calcd 464.20436, found 464.20413.

Macrocidin Z (6): A solution of Boc-protected macrocidin Z (15) $(238 \mathrm{mg}, 539 \mu \mathrm{mol})$ in dry $\mathrm{CH}_{2} \mathrm{Cl}_{2}$ $(10 \mathrm{~mL})$ was treated with TFA $(1.00 \mathrm{~mL})$, stirred for $15 \mathrm{~min}$, diluted with toluene $(100 \mathrm{~mL})$ and finally concentrated under reduced pressure. This procedure was repeated once to afford macrocidin $\mathrm{Z}(\mathbf{6})$ (183 mg, quant.) as a pale yellow foam; $R_{f}=0.60\left(10 \% \mathrm{MeOH}\right.$ in $\left.\mathrm{CH}_{2} \mathrm{Cl}_{2}\right) ;[\alpha]^{25} \mathrm{D}+126.1(\mathrm{c} 0.85, \mathrm{MeOH})$; IR $v_{\max } 2934(\mathrm{~m}), 2864(\mathrm{w}), 1696(\mathrm{~m}), 1656(\mathrm{~s}), 1607(\mathrm{~s}), 1508(\mathrm{~s}), 1448(\mathrm{~m}), 1338(\mathrm{~m}), 1250(\mathrm{~m}), 1217(\mathrm{~m}), 1177$ $(\mathrm{w}), 976(\mathrm{~m}), 843(\mathrm{w}) \mathrm{cm}^{-1},{ }^{1} \mathrm{H}-\mathrm{NMR}\left(500 \mathrm{MHz}, \mathrm{CD}_{3} \mathrm{OD}\right) \delta 0.83\left(\mathrm{~m}, 1 \mathrm{H}, \mathrm{CH}^{\mathrm{a}} \mathrm{HCC}=\mathrm{C}\right), 1.05(\mathrm{~d}, J=6.8 \mathrm{~Hz}$, $\left.3 \mathrm{H}, \mathrm{CH}_{3}\right), 1.13\left(\mathrm{~m}, 2 \mathrm{H}, \mathrm{CH}_{2} \mathrm{CMe}\right), 1.32\left(\mathrm{~m}, 1 \mathrm{H}, \mathrm{CH} H^{\mathrm{b}} \mathrm{CC}=\mathrm{C}\right), 1.79\left(\mathrm{~m}, 1 \mathrm{H}, \mathrm{CCH}^{\mathrm{a}} \mathrm{HC}=\mathrm{C}\right), 2.06(\mathrm{~m}, 1 \mathrm{H}$, 
$\left.\mathrm{CCH} H^{\mathrm{b}} \mathrm{C}=\mathrm{C}\right), 2.89\left(\mathrm{dd}, J=14.1,3.1 \mathrm{~Hz}, 1 \mathrm{H}, \mathrm{PhCH}{ }^{\mathrm{a}} \mathrm{H}\right), 3.07\left(\mathrm{dd}, J=14.1,3.9 \mathrm{~Hz}, 1 \mathrm{H}, \mathrm{PhCH} H^{\mathrm{b}}\right), 3.39$ (sex, $J=6.8 \mathrm{~Hz}, 1 \mathrm{H}, \mathrm{CHMe}), 4.10(\mathrm{~m}, 1 \mathrm{H}, \mathrm{CHN}), 4.53\left(\mathrm{~m}, 1 \mathrm{H}, \mathrm{CH}{ }^{\mathrm{a}} \mathrm{HO}\right), 4.64\left(\mathrm{dd}, J=13.4,9.5 \mathrm{~Hz}, 1 \mathrm{H}, \mathrm{CH} H^{\mathrm{b}} \mathrm{O}\right)$, $5.26(\mathrm{~m}, 1 \mathrm{H}, \mathrm{OHC}=\mathrm{C}), 5.68(\mathrm{~m}, 1 \mathrm{H}, \mathrm{C}=\mathrm{CHC}), 6.71\left(\mathrm{~m}, 2 \mathrm{H}, \mathrm{H}^{\text {ortho }}\right), 6.97\left(\mathrm{~m}, 2 \mathrm{H}, \mathrm{H}^{\text {meta }}\right) ;{ }^{13} \mathrm{C}-\mathrm{NMR}$ $\left(125 \mathrm{MHz}, \mathrm{CD}_{3} \mathrm{OD}\right) \delta 15.2(\mathrm{Me}), 28.1(\mathrm{CCC}=\mathrm{C}), 33.4(\mathrm{CC}=\mathrm{C}), 35.1$ (CCMe), $36.5(\mathrm{PhC}), 36.8(\mathrm{CMe})$, $63.8(\mathrm{HCN}), 67.9\left(\mathrm{OCH}_{2}\right), 102.1(\mathrm{NCC}=\mathrm{C}), 115.7,118.7\left(\mathrm{C}^{\text {ortho }}\right), 126.7\left(\mathrm{OCH}_{2} \mathrm{C}\right), 127.3\left(\mathrm{C}^{\text {para }}\right), 131.4$, 132.5 (C $\left.{ }^{\text {meta }}\right), 139.0\left(\mathrm{OCH}_{2} \mathrm{C}=\mathrm{C}\right), 157.3\left(\mathrm{C}^{\mathrm{ipso}}\right), 175.5(\mathrm{NCO}), 191.8(\mathrm{COH}), 197.1(\mathrm{CC}(\mathrm{O}) \mathrm{C}){ }^{1}{ }^{1} \mathrm{H}-\mathrm{NMR}$ $\left(500 \mathrm{MHz}, \mathrm{CDCl}_{3}\right) \delta 0.86(\mathrm{~m}, 1 \mathrm{H}), 1.07(\mathrm{~d}, J=6.9 \mathrm{~Hz}, 3 \mathrm{H}), 1.09-1.35(\mathrm{~m}, 3 \mathrm{H}), 1.80(\mathrm{~m}, 1 \mathrm{H}), 2.03(\mathrm{~m}, 1 \mathrm{H})$, $2.86(\mathrm{dd}, J=14.4,2.9 \mathrm{~Hz}, 1 \mathrm{H}), 3.20(\mathrm{dd}, J=14.4,3.7 \mathrm{~Hz}, 1 \mathrm{H}), 3.44(\mathrm{sex}, J=6.9 \mathrm{~Hz}, 1 \mathrm{H}), 4.14(\mathrm{t}, J=3.7 \mathrm{~Hz}$, 1H), $4.60(\mathrm{~m}, 2 \mathrm{H}), 5.27(\mathrm{~m}, 1 \mathrm{H}), 5.59(\mathrm{~m}, 1 \mathrm{H}), 6.17(\mathrm{~s}, 1 \mathrm{H}), 6.71(\mathrm{br}, 2 \mathrm{H}), 7.01(\mathrm{~m}, 2 \mathrm{H}) ;{ }^{13} \mathrm{C}-\mathrm{NMR}(125 \mathrm{MHz}$, $\left.\mathrm{CDCl}_{3}\right) \delta 15.1,27.0,32.4,34.2,35.5,36.1,62.3,67.4,100.9,114.8,118.1,125.2,125.7,130.3,131.7,137.9$, 156.0, 175.8, 192.2, 194.3 [not all quaternary C-atoms are visible in the JMOD in $\mathrm{CD}_{3} \mathrm{OD}$, some of them can be seen via HSQC or HMBC correlations]; HRMS (ESI): $m / z\left[\mathrm{C}_{20} \mathrm{H}_{23} \mathrm{NO}_{4}+\mathrm{H}^{+}\right]$: calcd 342.16998, found 342.16907.

\subsection{Antimicrobial Assay}

Minimum Inhibitory Concentrations (MIC) of compounds 1-6 were determined in serial dilution assays as described previously $[26,27]$ using different test microorganisms including Pichia anomala, Schizosaccharomyces pombe, Mucor hiemalis, Candida albicans, and Rhodotulas glutinis for fungal microorganisms; Micrococcus luteus, Bacillus subtilis, Staphyloccocus aureus and Mycobacterium smegmatis for Gram-positive bacteria; Chromobacterium violaceum, Escherichia coli and Pseudomonas aeruginosa for Gram-negative bacteria. A detailed protocol can be found in the Supporting Information.

\subsection{Cytotoxicity Assay}

The in vitro cytotoxicity $\left(\mathrm{IC}_{50}\right)$ of compounds 1-6 was determined against mammalian cell lines including mouse fibroblast L929 and Hela (KB3.1) cells according to our previously reported procedures $[26,27]$. A detailed protocol is given in the Supporting Information.

\subsection{Biofilm Inhibition Assay}

Staphylococcus aureus DSM 1104 from $-20{ }^{\circ} \mathrm{C}$ stock was incubated in $20 \mathrm{~mL}$ CASO (casein-peptone soymeal-peptone) medium at $37^{\circ} \mathrm{C}$ on a rotary shaker $\left(100 \mathrm{rpm}\right.$ ) overnight. The $\mathrm{OD}_{600}$ of the culture solution was measured and adjusted to match the turbidity of a 0.001 McFarland standard. A total of $150 \mu \mathrm{L}$ of CASO with $4 \%$ glucose broth was added together with the serial diluted compounds $(250-3.9 \mu \mathrm{g} / \mathrm{mL}$ ) and incubated in 96 well microtiter plates (TPP tissue culture ref.no 92196) for $18 \mathrm{~h}$ at $37^{\circ} \mathrm{C}$. The biofilm inhibition activity of the test compounds was evaluated by using $0.1 \%$ crystal violet staining (Thermo Fisher, Waltham, USA) following previously established protocols [28,29]. In brief, the supernatant was discarded, the biofilm stained at room temperature with $0.1 \%$ crystal violet for $15 \mathrm{~min}$ and washed three times by using PBS (phosphate-buffered saline) buffer, the dye in the biofilm was extracted with diluted acetic acid (30\%), and the absorbance was finally quantified in a plate reader (Synergy 2, BioTek, Santa Clara, USA) at $550 \mathrm{~nm}$. Methanol (5\%) was used as a negative control and microporenic acid A [28] (250-7.9 $\mu \mathrm{g} / \mathrm{mL})$ was used as a positive control. Standard deviations (SD) of three repeats with duplicates each were $15 \%$ or less. SD values are shown in Table S5 in the Supporting Information.

\subsection{Dispersion of Preformed Biofilm}

A cell suspension of Staphylococcus aureus strain DSM 1104 was adjusted to match the turbidity of a $0.001 \mathrm{McF}$ arland standard and incubated in 96-well tissue microtiter plates for $18 \mathrm{~h}$ in CASO with $4 \%$ glucose broth. The supernatant was removed from the wells and washed with $150 \mu \mathrm{L}$ PBS buffer; then, $150 \mu \mathrm{L}$ of the fresh media (CASO with $4 \%$ glucose broth) was added together with the serially diluted compounds $(250-3.9 \mu \mathrm{g} / \mathrm{mL})$ into the wells. The plates were further incubated for $24 \mathrm{~h}$ at $37^{\circ} \mathrm{C}$. 
Staining of the preformed biofilm and controls were described as for the biofilm inhibition [28,29]. All experiments were made in triplicates with two repetitions.

\section{Conclusions}

During the course of our search for new biologically active secondary metabolites, four previously undescribed oxazole carboxylic acid derivatives were isolated from the plant pathogenic fungus Phoma macrostoma. As far as we know, these metabolites constitute the first series of oxazole derivatives isolated from this genus. Investigation of the antimicrobial activity of the new isolates revealed that only compound 3 displayed moderate activity against Bacillus subtilis and Mucor hiemalis. Although none of the isolates displayed any antibacterial activity against $S$. aureus, compounds $\mathbf{2}$ and $\mathbf{3}$ showed moderate to weak inhibition of biofilm formation and preformed biofilm of the bacteria. Moreover, two known tetramic acids macrocidins, $A$ and $Z$, were also characterized. The so far unclear structure of macrocidin $\mathrm{Z}$ was confirmed in this study by its first total synthesis. Even though the macrocidins are well known for displaying a strong herbicidal activity, their biological effects have also been extensively evaluated in the present work and they turned out to possess an interesting antibiofilm effect against S. aureus. Thanks to their ability to inhibit biofilm formation, these are likely to be considered as promising candidates for the development of lead molecules that could function as adjunctive agents in combination therapy with antibiotics.

Supplementary Materials: Tables S1-S5, 1D, 2D NMR, ESIMS and HR-ESIMS spectra of compounds 1-6; NMR spectra of intermediates in the synthesis of 6. Protocol: Antimicrobial assay; Protocol: Cytotoxicity assay.

Author Contributions: B.M.K. contributed to fermentation, chemical analysis of the extracts, isolation of compounds, structure elucidation, bioactivity assays and manuscript writing. L.T. conceived and carried out the total synthesis of 6 and contributed to manuscript writing. H.Z. contributed to the antibiofilm assay. H.S. contributed to the antibiofilm assay and edited the manuscript. R.S. supervised the synthesis of 6 and co-edited the manuscript. M.S. supervised the project, contributed facilities, experimental guidance, edited and polished the manuscript. All authors have read and agreed to the published version of the manuscript.

Funding: Financial support by a personal PhD stipend from the German Academic exchange service DAAD to B.M.K. is gratefully acknowledged (programme ID-57440921). H.Z. is grateful for a personal PhD stipend from the "Drug Discovery and Cheminformatics for New Anti-Infectives (iCA)" and is financially supported by the Ministry for Science \& Culture of the German State of Lower Saxony (MWK no. 21-78904-63-5/19).

Acknowledgments: The authors wish to thank the CCFC, Benoit Goulet (curator of the culture collection) and Keith Seifert for providing the fungal material. We are also grateful to Wera Collisi and Christel Kakoschke for conducting the cytotoxicity assay and NMR spectroscopic measurements, respectively. Silke Reinecke as well as Esther Surges are thanked for expert assistance in the lab.

Conflicts of Interest: The authors declare no conflict of interest.

\section{References}

1. Kakkar, S.; Balasubramanian, N. A comprehensive review on biological activities of oxazole derivatives. BMC Chem. 2019, 13, 16. [CrossRef] [PubMed]

2. Kaur, R.; Palta, K.; Kumar, M.; Bhargava, M.; Dahiya, L. Therapeutic potential of oxazole scaffold: A patent review (2006-2017). Expert Opin. Therap. Pat. 2018, 28, 783-812. [CrossRef] [PubMed]

3. Zhang, W.; Liu, W.; Jiang, X.; Jiang, F.; Zhuang, H.; Fu, L. Design, synthesis and antimicrobial activity of chiral 2-(substituted-hydroxyl)-3-(benzo [d] oxazol-5-yl) propanoic acid derivatives. Eur. J. Med. Chem. 2011, 46, 3639-3650. [CrossRef] [PubMed]

4. Kumar, D.; Kumar, N.M.; Sundaree, S.; Johnson, E.O.; Shah, K. An expeditious synthesis and anticancer activity of novel 4-(3'-indolyl) oxazoles. Eur. J. Med. Chem. 2010, 45, 1244-1249. [CrossRef] [PubMed]

5. Moraski, G.C.; Chang, M.; Villegas-Estrada, A.; Franzblau, S.G.; Möllmann, U.; Miller, M.J. Structure-activity relationship of new anti-tuberculosis agents derived from oxazoline and oxazole benzyl esters. Eur. J. Med. Chem. 2010, 45, 1703-1716. [CrossRef] [PubMed]

6. Eren, G.; Ünlü, S.; Nuñez, M.T.; Labeaga, L.; Ledo, F.; Entrena, A.; Şahin, M.F. Synthesis, biological evaluation, and docking studies of novel heterocyclic diaryl compounds as selective COX-2 inhibitors. Bioorg. Med. Chem. 2010, 18, 6367-6376. [CrossRef] 
7. Ashton, W.T.; Sisco, R.M.; Dong, H.; Lyons, K.A.; He, H.; Doss, G.A.; Thornberry, N.A. Dipeptidyl peptidase IV inhibitors derived from $\beta$-aminoacylpiperidines bearing a fused thiazole, oxazole, isoxazole, or pyrazole. Bioorg. Med. Chem. Lett. 2005, 15, 2253-2258. [CrossRef]

8. Jadhav, R.D.; Kadam, K.S.; Kandre, S.; Guha, T.; Reddy, M.M.K.; Brahma, M.K.; Enose, A.A. Synthesis and biological evaluation of isoxazole, oxazole, and oxadiazole containing heteroaryl analogs of biaryl ureas as DGAT1 inhibitors. Europ. J. Med. Chem. 2012, 54, 324-342. [CrossRef]

9. Chandrasekhar, S.; Sudhakar, A. Total synthesis of bengazole A. Org. Lett. 2010, 12, 236-238. [CrossRef]

10. Davyt, D.; Serra, G. Thiazole and oxazole alkaloids: Isolation and synthesis. Mar. Drugs 2010, 8, $2755-2780$. [CrossRef]

11. Joshi, S.; Bisht, A.S.; Juyal, D. Systematic scientific study of 1, 3-oxazole derivatives as a useful lead for pharmaceuticals: A review. Pharma Innov. 2017, 6, 109.

12. Ichiba, T.; Yoshida, W.Y.; Scheuer, P.J.; Higa, T.; Gravalos, D.G. Hennoxazoles, bioactive bisoxazoles from a marine sponge. J. Am. Chem. Soc. 1991, 113, 3173-3174. [CrossRef]

13. Yokokawa, F.; Asano, T.; Shioiri, T. Total synthesis of the antiviral marine natural product (-)-hennoxazole A. Org. Lett. 2000, 2, 4169-4172. [CrossRef] [PubMed]

14. Shiomi, K.; Arai, N.; Shinose, M.; Takahashi, Y.; Yoshida, H.; Iwabuchi, J.; OMURA, S. New antibiotics phthoxazolins B, C and D produced by Streptomyces sp. KO-7888. J. Antibio. 1995, 48, 714-719. [CrossRef] [PubMed]

15. Graupner, P.R.; Carr, A.; Clancy, E.; Gilbert, J.; Bailey, K.L.; Derby, J.A.; Gerwick, B.C. The macrocidins: Novel cyclic tetramic acids with herbicidal activity produced by Phoma macrostoma. J. Nat. Prod. 2003, 66, 1558-1561. [CrossRef] [PubMed]

16. Graupner, P.R.; Gerwick, B.C.; Siddall, T.L.; Carr, A.W.; Clancy, E.; Gilbert, J.R.; Derby, J.A. Chlorosis inducing phytotoxic metabolites: New herbicides from Phoma macrostoma. ACS Symp. Ser. 2006, 927, 37-47.

17. Haase, R.G.; Schobert, R. Synthesis of the bioherbicidal fungus metabolite macrocidin A. Org. Lett. 2016, 18, 6352-6355. [CrossRef]

18. Andrade, C.K.; Rocha, R.O.; Vercillo, O.E.; Silva, W.A.; Matos, R.A. DCC/DMAP-mediated coupling of carboxylic acids with oxazolidinones and thiazolidinethiones. Synlett 2003, 35, 2351-2352. [CrossRef]

19. Barnickel, B.; Schobert, R. Toward the macrocidins: Macrocyclization via Williamson etherification of a phenolate. J. Org. Chem. 2010, 75, 6716-6719. [CrossRef]

20. Jouin, P.; Castro, B.; Nisato, D. Stereospecific synthesis of N-protected statine and its analogues via chiral tetramic acid. J. Chem. Soc. Perkin Trans. I 1987, 1177-1182. [CrossRef]

21. Hori, K.; Arai, M.; Nomura, K.; Yoshii, E. An efficient 3(C)-acylation of tetramic acids involving acyl migration of 4(O)-acylates. Chem. Pharm. Bull. 1987, 35, 4368-4371. [CrossRef]

22. Sengoku, T.; Nagae, Y.; Ujihara, Y.; Takahashi, M.; Yoda, H. A synthetic approach to diverse 3-acyltetramic acids via $\mathrm{O}$ - to $\mathrm{C}$-acyl rearrangement and application to the total synthesis of penicillenol series. J. Org. Chem. 2012, 77, 4391-4401. [CrossRef] [PubMed]

23. Bailey, K.L.; Derby, J. Fungal Isolates and Biological Control Compositions for the Control of Weeds. U.S. Patent No. 7772,155, 10 August 2010.

24. Chepkirui, C.; Richter, C.; Matasyoh, J.C.; Stadler, M. Monochlorinated calocerins A-D and 9-oxostrobilurin derivatives from the basidiomycete Favolaschia calocera. Phytochemistry 2016, 132, 95-101. [CrossRef] [PubMed]

25. Post, S.J.; Keohane, C.E.; Rossiter, L.M.; Kaplan, A.R.; Khowsathit, J.; Matuska, K.; Karanicolas, J.; Wuest, W.M. Target-based design of promysalin analogues identifies a new putative binding cleft in succinate dehydrogenase. ACS Infect. Dis. 2020, 6, 1372-1377. [CrossRef] [PubMed]

26. Becker, K.; Wessel, A.C.; Luangsa-ard, J.J.; Stadler, M. Viridistratins A-C, antimicrobial and cytotoxic benzo[j]fluoranthenes from stromata of Annulohypoxylon viridistratum (Hypoxylaceae, Ascomycota). Biomolecules 2020, 10, 805. [CrossRef]

27. Sandargo, B.; Michehl, M.; Praditya, D.; Steinmann, E.; Stadler, M.; Surup, F. Antiviral meroterpenoid rhodatin and sesquiterpenoids rhodocoranes A-E from the Wrinkled Peach Mushroom, Rhodotus palmatus. Organic Lett. 2019, 21, 3286-3289. [CrossRef]

28. Chepkirui, C.; Yuyama, K.; Wanga, L.; Decock, C.; Matasyoh, J.; Abraham, W.R.; Stadler, M. Microporenic acids A-G, biofilm inhibitors and antimicrobial agents from the basidiomycete Microporus sp. J. Nat. Prod. 2018, 81, 778-784. [CrossRef] 
29. Yuyama, K.T.; Chepkirui, C.; Wendt, L.; Fortkamp, D.; Stadler, M.; Abraham, W.R. Bioactive compounds produced by Hypoxylon fragiforme against Staphylococcus aureus biofilms. Microorganisms 2017, 5, 80. [CrossRef]

Sample Availability: Samples of the compounds are available from the authors.

Publisher's Note: MDPI stays neutral with regard to jurisdictional claims in published maps and institutional affiliations.

(C) 2020 by the authors. Licensee MDPI, Basel, Switzerland. This article is an open access article distributed under the terms and conditions of the Creative Commons Attribution (CC BY) license (http://creativecommons.org/licenses/by/4.0/). 